\title{
Synthesis of 6-Functionalized Tricyclodecadienones using Barton's Radical Decarboxylation Reaction. Generation of Tricyclo[5.2.1.02,6]decatrienone, a Norbornene Annulated Cyclopentadienone
}

\begin{abstract}
Jie Zhu, Antonius J.H. Klunder and Binne Zwanenburg*
Department of Organic Chemistry, NSR Center for Molecular Structure, Design and Synthesis, University of Nijmegen, Toernooiveld, 6525 ED Nijmegen, The Netherlands

Abstract: An effective synthesis of 6-functionalized endo-tricyclo[5.2.1.0 $2,6 \mathrm{Jdeca-4,8-dien-3-ones} \underline{7}$ starting from carboxylic acid 6 has been accomplished whereby the chemical scope of the tricyclodecadienone system $\underline{I}$ as a synthetic equivalent of cyclopentadienone has been expanded. Bridgehead bromide $7 d$ gives upon treatment with base access to norbornene annulated cyclopentadienone $\underline{10}$ which rapidly undergoes either regioselective nucleophilic addition or Diels-Alder cyclization depending on the applied reaction conditions.
\end{abstract}

\section{Introduction}

In recent years, it was demonstrated that the endo-tricyclo $\left[5.2 .1 .0^{2,6}\right]$ decadienone system 1 is an extremely useful synthon for a great variety of naturally occurring cyclopentanoids ${ }^{1}$. The basic strategy underlying this approach is depicted in Scheme 1. It generally involves stereoselective nucleophilic

Scheme 1<smiles>O=C1C=CC2CC1C1C=CC2C1</smiles>

1

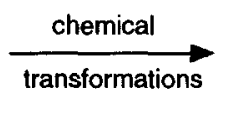

addition to the enone moiety, followed by chemical transformations to introduce the desired<smiles>[R]C1([2H])CC(=O)C2C3C=CC(C3)C21</smiles>

$\underline{2}$

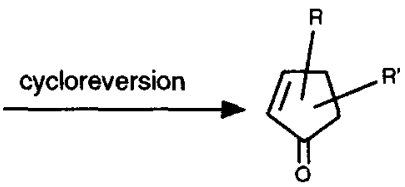

3 functionalities. Thermal cycloreversion of the appropriately functionalized tricyclodecenone $\underline{\mathbf{2}}$ employing the technique of flash vacuum thermolysis ultimately leads to the desired cyclopentenones $\underline{3}$. The availability of both antipodes of $\underline{1}$ in enantiopure form, either by enzymatic resolution ${ }^{1 a, 2}$ or asymmetric synthesis $^{3}$ completes this strategy and makes it extremely useful for the enantioselective synthesis of a 
variety of cyclopentenoids.

The synthetic merit of the endo-tricyclo[5.2.1.0 $\left.0^{2,6}\right]$ decadienone $\underline{1}$ is nicely demonstrated by the efficient enantioselective synthesis of 4-hydroxycyclopentenone $\underline{4}^{1 \mathrm{~h}, 4}$ which is the essential intermediate in the synthesis of clavulones $\underline{\mathbf{5}}$. Key structure in this route to clavulones $\underline{\mathbf{5}}$ is tricyclic carboxylic acid $\underline{\mathbf{6}}$ which is readily available from cyclopentadiene and benzoquinone ${ }^{5}$. Furthermore, it can conveniently be obtained in enantiopure form ${ }^{2 a}$. Decarboxylation of $\underline{6}$ to parent endo-tricyclodecadienone $\underline{7}(\mathrm{X}=\mathrm{H})$ is achieved in dimethylformamide at $100^{\circ} \mathrm{C}$ in excellent yield without racemization. Retrosynthetic analysis reveals that the substituent $\mathrm{X}$ as present at the 6-position in tricyclodecadienone $\underline{\mathbf{Z}}$ eventually appears at the $\mathrm{C}_{2}$-position in cyclopentenone $\underline{4}$. Hence, by choosing the appropriate substituent at $\mathrm{C}_{6}$ in $\underline{\mathbf{7}}$, $\alpha$-substituted cyclopentenones $\underline{4}$ and accordingly the corresponding $\alpha$-subsituted clavulones are within reach. Interesting examples of such $\alpha$-substituted clavulones are the $\alpha$-halogenated marine prostanoids, such as halovulones $\underline{8}(\mathrm{X}=\mathrm{Cl}, \mathrm{Br} \text { and } \mathrm{I})^{6}$ and punaglandines $\underline{9}^{7}$. Therefore, the halodecarboxylation of carboxylic acid $\underline{6}$ was

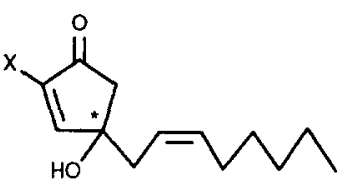

$\underline{4}$

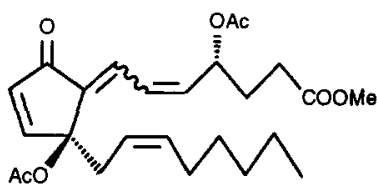

$\underline{5}$

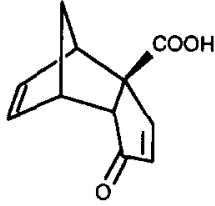

$\underline{6}$

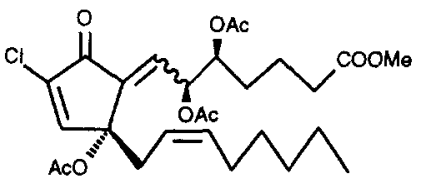

9<smiles>[Y]C12C=CC(CC1)C1C=CC2C1</smiles>

$\underline{7}$<smiles>O=C1C=CC2CCC1C2</smiles>

10

investigated to broaden the synthetic scope of the tricyclodecadienone system. In this paper, the synthesis of a variety of 6-substituted tricyclodecadienones $\underline{7}$ using Barton's radical chain decarboxylation process is reported. In addition, the surprisingly facile dehydrohalogenation of $\underline{7}(\mathrm{X}=\mathrm{Br})$ to form the elusive tricyclodecatrienone $\underline{\mathbf{1 0}}$ will be described ${ }^{8}$.

\section{Results and discussion}

The radical chain decarboxylation process involving the thermal or photochemical decomposition of thiohydroxamic esters, as reported by Barton et al. ${ }^{9}$, seems a suitable method for the halodecarboxylation of 6. The high yields for this halodecarboxylation reaction observed for primary, secondary and tertiary carboxylic acids 9,10 and the avoidance of molecular halogen as the halogen radical source makes this method very attractive. It is obvious that halodecarboxylation methods using molecular halogen, such as the Hunsdiecker type processes, cannot be applied for the halodecarboxylation of $\mathbf{6}$ because of the presence of the reactive olefinic norbornene moiety. Also the use of lead tetracetate in the presence of metal halides does not seem a good choice because this aggressive reagent may cause unwanted reactions with the relative labile unsaturated tricyclodecadienone system and, moreover, the work-up is usually 
troublesome ${ }^{11}$. The attractive feature of Barton's radical decarboxylation process is its synthetic scope. By varying the radical trapping agent in principle a great variety of different substitution products $\underline{7}$ can be obtained (Scheme 2). During the reaction process, the radical $\underline{12}$ may exhibit considerable stability as on

\section{Scheme 2}

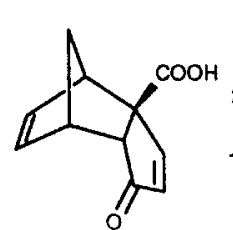

6
1. $(\mathrm{COCl})_{2}, \mathrm{DMF}$

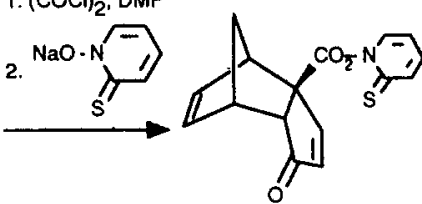

$\underline{11}$
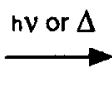

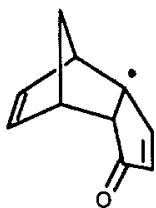

12
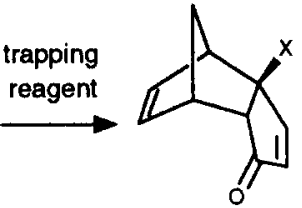

$\underline{7}$

one hand it constitutes a tertiary radical and on the other hand it is stabilized by the adjoining enone system. Moreover, the rigidity of the strained system probably prevents intramolecular interaction with the $\mathrm{C}_{8}-\mathrm{C}_{9}$ norbornene type double bond which could lead to cyclopropane ring formation. The considerations above suggest a rather selective behavior of radical 12 towards radical trapping agents, which may be beneficial for the product formation.

The preparation of the required thiohydroxamic ester $\underline{11}$ was carried out by converting acid $\underline{6}$ into the corresponding acyl chloride using oxalyl chloride, followed by treatment with the sodium salt of $\mathrm{N}$-hydroxypyridine-2-thione (Scheme 2). Attempts to isolate and characterize $\mathrm{N}$-acyloxypyridine-2-thione 11 failed due to its instability under work-up conditions. Therefore, in all experiments described hereafter, the thiohydroxamic ester $\underline{\mathbf{1 1}}$ was not isolated but immediately subjected to the radical decarboxylation process.

In order to gain insight into the efficiency of this radical decarboxylation process the well-documented replacement of the carboxylic acid function by hydrogen was first studied ${ }^{9 c}$. For this purpose $\underline{11}$ was heated in benzene at $60^{\circ} \mathrm{C}$, while irradiating with a tungsten lamp, in the presence of a large excess of t-butyl mercaptan as the hydrogen donor. A mixture consisting of parent tricyclodecadienone $\underline{\mathbf{7 a}}$ and pyridyl sulfide $\underline{\mathbf{7 b}}$ was obtained in yields of $60 \%$ and $15 \%$, respectively (Scheme 2; Table 1). The latter product $\underline{7 b}$ was formed in almost quantitative yield when no suitable radical trapping agent, such as t-butyl mercaptan, was present. The formation of some pyridyl sulfide $\underline{7 b}$ despite the presence of a large excess of $t$-butyl mercaptan is indicative of the relative stability of radical 12. It should be noted that no products arising from radical rearrangement or ring closure reactions of the tricyclodecadienone system were observed ${ }^{12}$.

The halodecarboxylation of $\underline{6}$ was studied under standard conditions. For the synthesis of 6-chlorotricyclodecadienone $\underline{7 c}$ a solution of the acid chloride of $\underline{6}$ in tetrachloromethane was added to a suspension of the sodium salt of $\mathrm{N}$-hydroxypyridine-2-thione in refluxing tetrachloromethane while irradiating with a tungsten lamp. A mixture of two products was obtained from which the desired chloride $\underline{7 \mathrm{c}}$ was isolated as the minor product in $10 \%$ yield only. The major product, which was obtained in $70 \%$ yield, was identified as pyridyl sulfide $\underline{\mathbf{7}} \mathbf{b}$. The high selectivity of bridgehead radical $\underline{\mathbf{1 2}}$ for reaction with hydroxamic ester 11 can readily be explained by assuming a low energy profile for radical $\underline{12}$ which apparently is too stable to effectively induce $\mathrm{C}-\mathrm{Cl}$ bond cleavage in tetrachloromethane. The formation of $\underline{7 b}$ appears to be a rather common side reaction in those cases where rather unreactive radical trapping 
Table 1

\begin{tabular}{cccccccccc}
\hline & $\underline{\mathbf{7 a}}$ & $\underline{\mathbf{7 b}}$ & $\underline{\mathbf{7 c}}$ & $\underline{\mathbf{7 d}}$ & $\underline{\mathbf{7 e}}$ & $\underline{\mathbf{7 f}}$ & $\underline{\mathbf{7 g}}$ & $\underline{\mathbf{7 h}}$ & $\underline{\mathbf{7 i}}$ \\
\hline $\mathrm{X}$ & $\mathrm{H}$ & $\mathrm{SPy}$ & $\mathrm{Cl}$ & $\mathrm{Br}$ & $\mathrm{I}$ & $\mathrm{CH}_{3} \mathrm{~S}$ & $\mathrm{PhS}$ & $\mathrm{PhSe}$ & $\mathrm{OH}$ \\
$\begin{array}{c}\text { trapping } \\
\text { reagent }\end{array}$ & $\mathrm{t}-\mathrm{BuSH}$ & none & $\mathrm{t}-\mathrm{BuOCl}$ & $\mathrm{BrCCl}_{3}$ & $\mathrm{HCl}_{3}$ & $(\mathrm{MeS})_{2}$ & $(\mathrm{PhS})_{2}$ & $(\mathrm{PhSe})_{2}$ & $\begin{array}{c}(\mathrm{PhS})_{3} \mathrm{Sb} \\
\mathrm{H}_{2} \mathrm{O}_{2} \\
\text { yield(\%) }\end{array}$ \\
60 & $>90$ & 30 & 93 & 62 & 22 & 42 & 94 & 40 \\
\hline
\end{tabular}

agents such as tetrachloromethane are used ${ }^{10 \mathrm{~b}}$. Attempts to promote the formation of $\underline{7 c}$ by modifying the reaction condition and using other chlorine donors, such as $\mathrm{N}$-chlorosuccinimide and t-butylhypochlorite, led only to slight improvements. Eventually, chloride $\mathbf{7 c}$ was obtained in an optimum yield of $30 \%$ by applying $t$-butylhypochlorite in tetrachloromethane.

A much better result was obtained for the bromodecarboxylation of 6 . In bromotrichloromethane, which is the commonly used radical trapping agent in this Barton decarboxylation process, an effective bromodecarboxylation of $\underline{6}$ was observed giving 6-bromotricyclodecadienone $\underline{7 d}$ in an excellent yield of 93\%. Only a trace of pyridyl sulfide $\underline{\mathbf{7 b}}$ had been formed indicating that the $\mathrm{C}-\mathrm{Br}$ bond in bromotrichloromethane is apparently weak enough to let this solvent successfully compete with the thiohydroxamic ester in capturing the 6-tricyclodecadienonyl radical 12. A similar saticfactory result was obtained when iodoform was used as the trapping agent. By generating the radical $\underline{12}$ in toluene in the presence of an excess of iodoform 6-iodotricyclodecadienone $7 \mathrm{e}$ was isolated in $62 \%$ yield as a crystalline compound. No pyridyl sulfide $\underline{\mathbf{7 b}}$ was formed in this iododecarboxylation of $\underline{\mathbf{6}}$. This result further substantiates the selective nature of bridgehead radical $\underline{\mathbf{1 2}}$.

Having successfully accomplished the halodecarboxylation of acid $\underline{\mathbf{6}}$ using Barton's procedure, the question arose whether this methodology can be applied for the introduction of other heteroatom containing functionalities at the $\mathrm{C}_{6}$-position in $\underline{\mathbf{7}}$. The formation of pyridyl sulfide $\underline{\mathbf{7 b}}$ from $\underline{\mathbf{1 1}}$ in benzene indicates that the introduction of other sulfur containing substituents at $\mathrm{C}_{6}$ in $\underline{7}$ seems feasible. The radical chalcogenation has already been studied by Barton et al. ${ }^{13}$ and was shown to proceed quite well in many cases, provided an efficient trapping agent is selected which can effectively compete with the thiohydroxamic ester.

When using dimethyl disulfide as the trapping agent under standard reaction conditions, carboxylic acid 6 only gave a disappointingly low yield (22\%) of tricyclic methyl sulfide $\underline{7 f}$. Again the major product isolated was pyridyl sulfide $\underline{\mathbf{7 b}}$. Using the somewhat more reactive diphenyl disulfide as the trapping agent only slightly affected the efficiency of this chalcogenation process. The disulfide bond in both dimethyl disulfide and diphenyl disulfide is apparently too strong to effectively compete with the thiohydroxamic ester in trapping the tricyclodecadienyl radical $\underline{\mathbf{1 2}}$. Decreasing the reaction temperature to $0^{\circ} \mathrm{C}$ which, as reported by Barton $e t a l^{13}$., should disfavor the formation of the undesired pyridyl sulfide $\mathbf{7 b}$ did not lead to improvement. Contrary to Barton's observations, the yields of the desired sulfides $\underline{7 g}$ considerably dropped while pyridyl sulfide $\underline{\mathbf{7 b}}$ was now obtained in almost quantitative yield. These results indicate that the nature of the intermediate free carbon radical plays an determining role in the product formation. In the 
present case lowering the temperature favors the more selective radical addition of $\underline{\mathbf{1 2}}$ to thiohydroxamic ester 11. Although a reversible formation of $\underline{12}$ from the initial addition product cannot be excluded, the subsequent reaction of 12 with the disulfides is apparently too slow to prevent the preferential formation of pyridyl sulfide $\underline{\mathbf{7 b}}$.

In agreement with the above reasoning, the use of the much more reactive diphenyl diselenide as the radical trapping agent gave efficient capture of carbon radical 12 affording 6-phenylselanyltricyclodecadienone $\underline{7 h}$ in an excellent yield of $94 \%$.

The transformation of the 2-carboxylic acid function in $\underline{6}$ into 6-oxygen substituted tricyclodecadienones such as alcohol $\underline{7} \mathbf{i}$ is of great importance as these compounds may eventually give rise to 3-oxycyclopent-2-enones by the sequence of events depicted in Scheme 1. These substructures occur in natural cyclopentenoids, e.g. kjellmanianone ${ }^{14}$. The transformation of carboxylic acid moiety into an oxy group is usually a multistep operation involving either some oxidation process e.g. a Baeyer-Villiger oxidation of the corresponding ketone, or a decarboxylative conversion to a leaving group e.g. a halide, which then allows oxygen substitution using a metal hydroxide or alkoxide. As radicals are usually efficiently trapped by triplet oxygen, the synthesis of bridgehead alcohol $\underline{\mathbf{7}}$ was attempted applying Barton's decarboxylation procedure in the presence of oxygen ${ }^{9 c}$. Unfortunately, no satisfactory results were obtained. Again the formation of the pyridyl sulfide $\mathbf{7 b}$ turned out to be much more effective than capture of molecular oxygen. Recently, a new and synthetically more attractive method for the oxydecarboxylation of thiohydroxamic esters was develope ${ }^{15}$ involving the generation of the carbon radical in the presence of antimony trisphenyl sulfide which leads to the formation of the corresponding carbon substituted bisphenyl antimonate (Scheme 3). Oxidation of this rather unstable antimonate with molecular oxygen, followed by aqueous work up, then produces the desired alcohol. When this procedure was applied to tricyclic carboxylic acid $\underline{6}$ by adding antimony trisphenyl sulfide to thiohydroxamic ester 11 at room temperature, in the dark and under an oxygen atmosphere followed by the addition of water, 6-hydroxytricyclodecadienone $\underline{7} \mathbf{i}$ was isolated in $40 \%$ yield after column chromatography (Scheme 3, Table 1). This result suggests that tricyclic antimonate $\underline{\mathbf{1 3}}$ has indeed been formed. A second tricyclic

Scheme 3

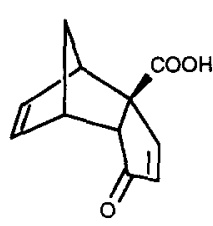

$\underline{6}$

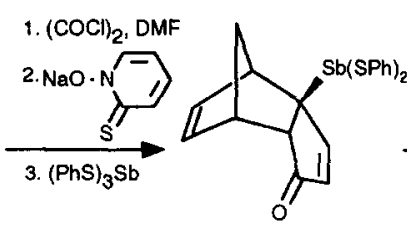

$\underline{13}$

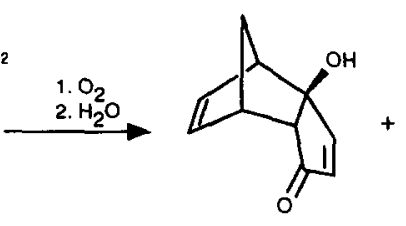

7i $(40 \%)$

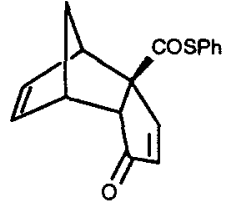

$14(25 \%)$

compound was isolated in $25 \%$ yield to which, on basis of spectral evidence, structure 14 was assigned. This product is clearly the result of thiophenolate addition to thiohydroxamic ester $\underline{11}$ which apparently competes with the radical reaction. The occurrence of appreciable amounts of thiophenolate in the reaction mixture is probably the result of decomposition of the antimony trisphenyl sulfide which is known to be water and air sensitive. Although there is certainly room for improving this oxydecarboxylation of $\underline{6}$ into 
7i, no further attempts were made as a much more effective route to 6-substituted oxytricyclodecadienone was found starting from tricyclic bromide $\mathbf{7 d}$ (vide infra).

In view of our interest in functionalized cage compounds, the synthesis of bridgehead bromide 18a and phenylselenide $\underline{18 \mathrm{~b}}$ starting from 1,3-bishomocubanone carboxylic acid $\underline{17}$ was undertaken (Scheme 4). Irradiation of tricyclic ester $\underline{15}$ in toluene gave 1,3-bishomocubanone ester $\underline{16}$ which on alkaline

Scheme 4

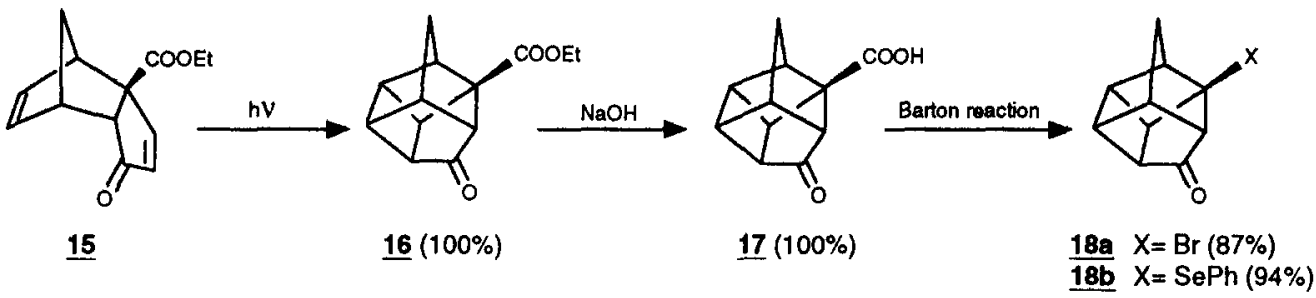

hydrolysis afforded carboxylic acid $\underline{17}$ in a quantitative overall yield. The bromodecarboxylation and the phenylselenodecarboxylation of $\underline{\mathbf{1 7}}$, following the procedure described for the preparation of $\underline{\mathbf{7 d}}$ and $\underline{\mathbf{7 h}}$, gave 18a and 18b, respectively, in excellent yields.

The results described above show that an excellent route to a variety of 6-substituted tricyclodecadienones $\underline{\mathbf{7}}$ starting from readily available tricyclic carboxylic acid $\underline{\mathbf{6}}$ has been attained using the thiohydroxamic radical chemistry. The only drawback encountered is the relatively high stability of bridgehead radical $\underline{12}$ which necessitates rather reactive radical trapping reagents in order to suppress the formation of pyridyl sulfide $\underline{\mathbf{7 b}}$ and to obtain acceptable yields of the desired 6-functionalized tricyclodecadienones $\mathbf{7}$.

The 6-substituted halides $\underline{7}$,, d,e appeared to be rather reactive compounds. At room temperature they slowly decompose as indicated by their darkening. They can however be kept in the refrigerator for months without noticeable change. In order to uncover the chemical properties of these halides $\underline{\mathbf{Z}}$ in connection with their application in the synthesis of halovulones and punaglandines, the behavior of tricyclic bromide $\underline{\mathbf{7 d}}$ in nucleophilic medium was investigated. A fast reaction was observed when $\underline{\mathbf{7 d}}$ was stirred in methanol in the presence of some potassium hydroxide. At room temperature the bromide disappeared within a few minutes to give a major compound together with a minor amount of a second product. Both compounds could readily be separated by column chromatography. Spectral analysis of both compounds immediately revealed the absence of bromine. The major compound isolated contained a methoxy group while its NMR-spectral features closely resembled that of the original bromide 7d suggesting this product to be 6-methoxy-endo-tricyclodecadienone 19 (Scheme 5). To prove the endo-configuration, photocyclization of 19 , which is a well-established process for endo-tricyclodecadienones, was performed by irradiation in toluene, affording 1,3-bishomocubanone $\underline{\mathbf{2 0}}$ in quantitative yield. This reaction unambiguously confirms that structure $\underline{19}$ is correct. The minor compound exhibited a rather complicated ${ }^{1} \mathrm{HNMR}$-spectrum whereas the ${ }^{13} \mathrm{CNMR}$-spectrum indicated a high degree of unsaturation which together with the observed number of carbon resonances suggested a product with a dimeric structure. On the basis of these spectral features together with mechanistic considerations dimeric structure $\underline{21}$ was assigned. 


\section{Scheme 5}

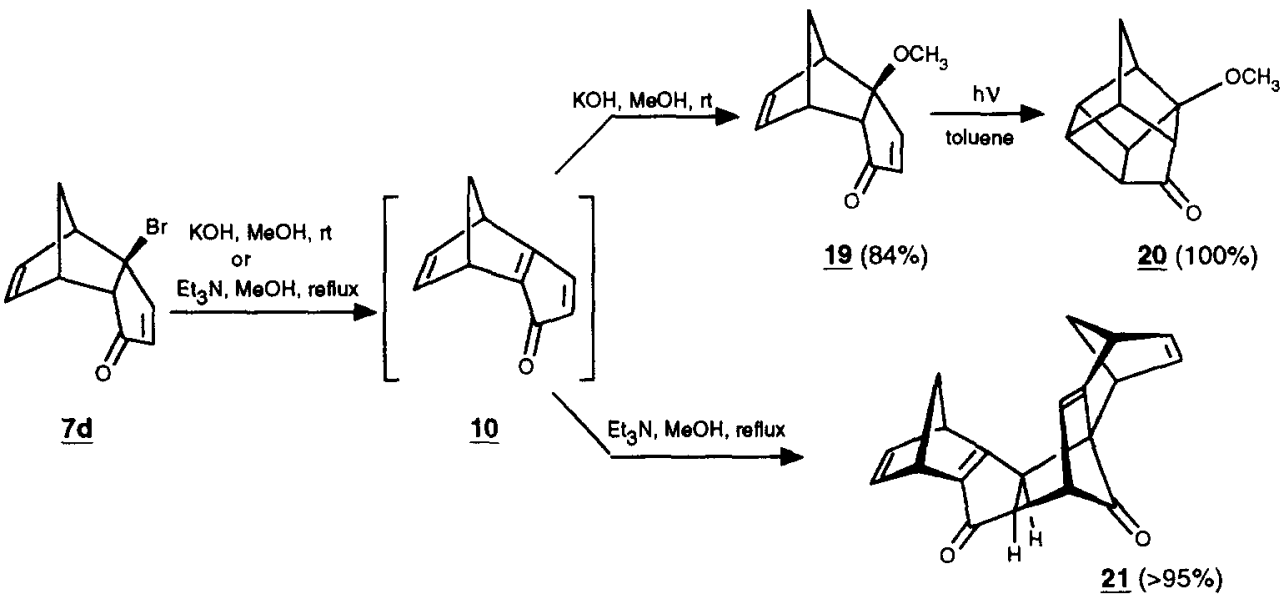

Interestingly, a nearly quantitative formation of $\underline{\mathbf{2 1}}$ was achieved by refluxing $\underline{\mathbf{7 d}}$ in methanol containing triethylamine as the base. The unambiguous proof for structure $\underline{21}$ was obtained by an X-ray diffraction analysis (Figure 1) ${ }^{16}$.

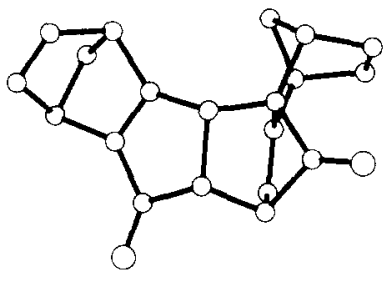

Figure 1. X-ray structure of 21

The high yield formation of both $\underline{\mathbf{1 9}}$ and $\underline{\mathbf{2 1}}$ from $\underline{\mathbf{7 d}}$ can conveniently be rationalized by assuming an initial base-induced enolization of $\underline{\mathbf{7 d}}$ followed by rapid elimination of the 6-bromo substituent to give the highly strained norbornene annulated cyclopentadienone 10. This elusive cyclopentadienone then, depending on the reaction conditions, undergoes either conjugate addition of methoxide or dimerization to give 19 and $\underline{21}$, respectively.

The occurrence of such a facile dehydrobromination of $\mathbf{7 d}$ to give 10 is surprising in view of the considerable increase in energy that goes along with the formation of such an annulated cyclopentadienone system. Cyclopentadienones are extremely reactive compounds and generally immediately dimerize in a Diels-Alder reaction after their formation ${ }^{17}$. The isolation of the complicated heptacyclic dione 21 which is one of the conceivable Diels-Alder dimerization adducts of $\underline{10}$ therefore presents firm evidence for its intermediacy in the reaction of bromide $\underline{\mathbf{7 d}}$ with either potassium hydroxide or triethylamine in methanol. 
Apparently, the conjugate addition of methoxide to the $C_{2}-C_{6}$ enone system in $\underline{10}$ to give $\underline{19}$ can effectively compete with the [4+2]-dimerization. To our knowledge this is the first example of a successful trapping of a cyclopentadienone intermediate by nucleophilic conjugate addition. The exclusive formation of 19 shows that this conjugate addition of the methoxide nucleophile to $\underline{10}$ is regio- and stereoselective. The observed regiospecificity agrees with the higher reactivity of the more strained $C_{2}-C_{6}$ enone moiety as compared with the peripheral $\mathrm{C}_{4}-\mathrm{C}_{5}$ enone. The observation of exclusive methoxide attack at $\mathrm{C}_{6}$ in $\underline{\mathbf{1 0}}$ from the exo-face leading to the endo-tricyclodecadienone system is probably of steric origin although stereoelectronic effects may also play a role. Inspection of molecular models shows that addition of a nucleophile from this exo-face may sterically be slightly favored over attack from the endo-face.

For the dimerization of 10 , which proceeds via a [4+2]-cyclization, eight possible combinations can be envisaged. However, molecular modeling studies involving all conceivable transition states clearly reveal that only the transition state involving the peripheral enone moiety and leading to endo-dicyclopentadienone $\underline{21}$ is stereochemically feasible. Involvement of the very reactive central $\mathrm{C}_{2}-\mathrm{C}_{6}$ double bond in this Diels-Alder dimerization leads to highly unfavourable transition states due to severe van der Waals interactions. The steric constraints encountered in the dimerization of $\underline{10}$ leading to $\underline{21}$ suggest that this process may be relatively slow as compared to the dimerization of monocyclic cyclopentadienones. This would explain the successful trapping of tricyclic cyclopentadienone $\underline{\mathbf{1 0}}$ with potassium methoxide in methanol to give $\underline{19}$.

Additional evidence for the relatively slow dimerization rate of $\underline{10}$ was obtained from its trapping in a crossed Diels-Alder reaction with cyclopentadiene. When the dehydrobromination of $\underline{7 \mathbf{d}}$ was carried out under the conditions used for the preparation of dimer $\underline{\mathbf{2 1}}$, however, now in the presence of a five-fold excess of cyclopentadiene, hardly any dimer $\underline{21}$ was formed. Instead, a mixture of cycloaddition products $\underline{\mathbf{2 2}}$ and $\underline{\mathbf{2 3}}$ was obtained in a ratio of $1: 2$ and in $80 \%$ total yield (Scheme 6). The structures of $\underline{\mathbf{2 2}}$ and $\underline{\mathbf{2 3}}$

Scheme 6

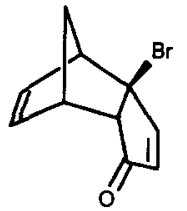

7d

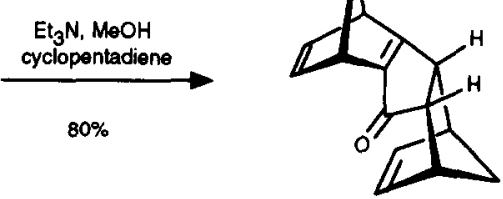

$\underline{22}$

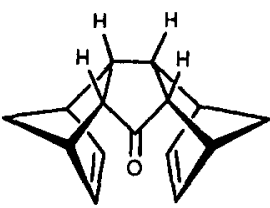

$\underline{24}$

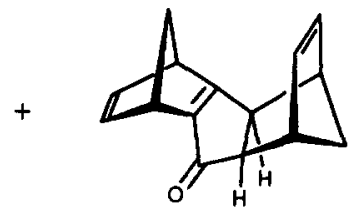

$\underline{23}$

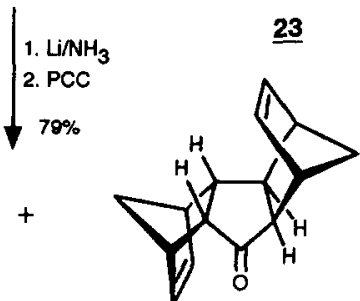

25

were secured by correlation with known compounds. For this purpose the mixture of $\underline{\mathbf{2 2}}$ and $\underline{\mathbf{2 3}}$ was reduced with lithium in ammonia and subsequently oxidized with pyridinium chlorochromate to give $\underline{24}$ 
and $\underline{25}$ (ratio 1:2). After separation by column chromatography the ${ }^{1} \mathrm{H}$ - and ${ }^{13} \mathrm{CNMR}$ spectra of both compounds indicated that these structures were highly symmetric. In principle, there are four possible structures which fulfill this requirement for either $\mathrm{D}$ or $\mathrm{C}_{2}$-symmetry viz. $\underline{\mathbf{2 4}}, \underline{\mathbf{2 5}}, \underline{\mathbf{2 8}}$ and $\underline{29}$ (Schemes 6,7 and 8). Since the NMR-spectra of the isolated adducts did not allow an unambiguous structure assignment, independent synthesis of some of the possible candidates was pursued. Compounds $\underline{\mathbf{2 5}}$ and $\underline{\mathbf{2 8}}$ were readily available by the Diels-Alder reaction of parent endo- and exo-tricyclodecadienones $\underline{\mathbf{7 a}}$ and $\underline{\mathbf{2 6}}$, respectively, with cyclopentadiene under Lewis acid catalysis (Scheme 7$)^{18}$. After separation from the

Scheme 7<smiles>O=C1C=CC2CCC1C2</smiles>

7a<smiles>O=C1C=CC2CC1C1C=CC2C1</smiles>

$\underline{26}$

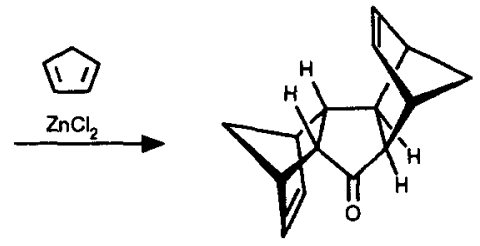

$\underline{25}$

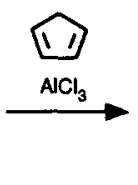

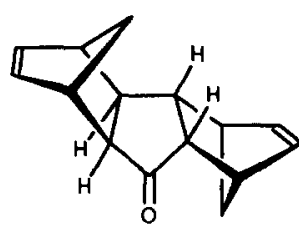

$\underline{28}$

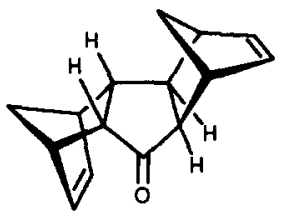

$\underline{27}$

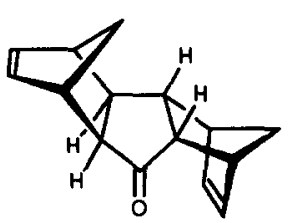

$\underline{27}$

(mirror image of 27)

non-symmetrical adduct 27 , which was formed in both reactions, comparison of the spectral data of these $\mathrm{C}_{2}$-symmetrical adducts $\underline{\mathbf{2 5}}$ and $\underline{\mathbf{2 8}}$ immediately identified one of the unknown products obtained in the reactions depicted in Scheme 6 as $\underline{\mathbf{2 5}}$. The other unknown compound must therefore possess either structure 24 or 29 (Scheme 8). Differentiation between these structures is in principle conceivable by their difference in photochemical behavior. Only for $\mathbf{2 4}$ irradiation is expected to give rapid intramolecular $[2+2]$-cycloaddition to cage ketone $\underline{\mathbf{3 0}}$ due to the close proximity of the two olefinic bonds. Since ketone

Scheme 8

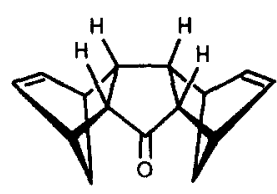

$\underline{29}$

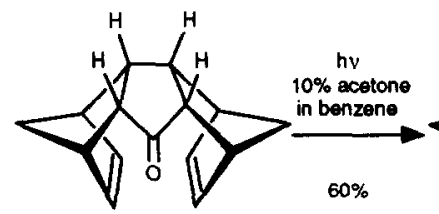

$\underline{24}$

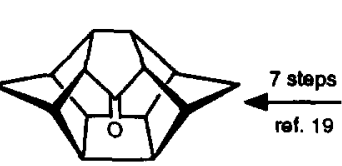

$\underline{30}$

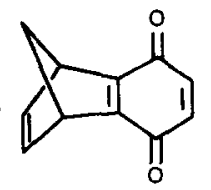

$\underline{31}$

30 is a known compound ${ }^{19}$ comparison of spectral data will allow unequivocal assignment of this second unknown structure. Indeed, when this adduct was subjected to irradiation in benzene containing $10 \%$ of acetone cage ketone $\underline{\mathbf{3 0}}$ was obtained in $60 \%$ yield and accordingly identifying its photoprecursor as $\underline{\mathbf{2 4}}$. It 
should be mentioned that ketone $\underline{\mathbf{3 0}}$ can also be obtained from related benzoquinone $\underline{\mathbf{3 1}}$ in 7 steps and in an overall yield of $3.9 \%$.

The formation of adducts $\underline{\mathbf{2 2}}$ and $\underline{\mathbf{2 3}}$ in the crossed Diels-Alder with cyclopentadiene demonstrates that the $[4+2]$ cycloaddition does not occur at the central $\mathrm{C}_{2}-\mathrm{C}_{6}$ enone system despite its higher reactivity. Even with a reactive diene such as cyclopentadiene, the steric barrier imposed by either the methylene or ethene bridge can not be overcome and the cycloaddition reaction takes place exclusively at the peripheral enone system in $\underline{\mathbf{1 0}}$ and in the endo-fashion.

It is of interesting to note that tricyclodecatrienone $\underline{\mathbf{1 0}}$ constitutes a chiral cyclopentadienone and therefore will allow the synthesis of enantiopure products. This is nicely demonstrated by the synthesis of enantiopure dimer (-)-21 from enantiopure bromide (-)- $\underline{\mathbf{7}} \underline{\mathrm{d}}$ by treatment with triethyl amine in methanol. The chemistry of tricyclic bromide $\mathbf{7 d}$ described above opens interesting new manners for the synthesis of natural products and cage compounds via the intermediacy of norbornene annulated cyclopentadienone 10 .

\section{Experimental section}

\section{General remarks}

Melting points were measured with a Reichert Thermopan microscope and are uncorrected. IR spectra were recorded on a Perkin-Elmer 298 infrared spectrophotometer. ${ }^{1} \mathrm{H}$ and ${ }^{13} \mathrm{C}-\mathrm{NMR}$ spectra were recorded on a Bruker AM-400 spectrophotometer, using TMS as an internal standard. For mass spectra a double focussing VG 7070E mass spectrometer was used. Capillary GC analyses were performed using a Hewlett-Packard 5890A gas chromatograph, containing a cross-linked methyl silicone column (25m). Flash chromatography were carried out at a pressure of ca. 1.5 bar, a column length of $15-25 \mathrm{~cm}$ and a column diameter of 1-4 cm, using Merck Kieselgel $60 \mathrm{H}$. Elemental analyses were performed on a Carlo Erba Instruments CHNS-O 1108 Elemental analyzer. Optical rotations were determined on a Perkin-Elmer 241 polarimeter. All solvents used were dried and distilled according to the standard procedures.

\section{General procedure for Barton's radical decarboxylation reaction}

\section{A: Preparation of acid chlorides}

The acid chlorides were prepared immediately before use and were not purified. Thus, a solution of the corresponding carboxylic acid $(1 \mathrm{mmole})$ in benzene $(5 \mathrm{ml})$ was treated with oxalyl chloride $(0.3 \mathrm{ml})$ and a drop of dimethyl formamide. After stirring for 2 hrs at room temp. with protection from moisture, the solvent and the excess of oxalyl chloride were evaporated in vacuo and the residual acid chloride was used as such.

\section{B: Barton's radical reaction}

Acid chloride (1 mmole) in appropriate solvent $(5 \mathrm{ml})$ was added dropwise (adding rates depend on the reaction) to a dried, stirred suspension of $\mathrm{N}$-hydroxypyridin-2-thione sodium salt (1.2 mmole) in the same solvent and containing the radical trapping reagent. During the addition the mixture was heated at reflux and irradiated with a $250 \mathrm{w}$ tungsten lamp under an inert atmosphere. After completion of the addition the 
reaction mixture was cooled to room temp. and evaporated to dryness. The crude product was purified by flash chromatography over silica gel and/or recrystallization.

endo-Tricyclo[5.2.1.0.6 $]$ deca-4,8-dien-3-one 7a ${ }^{3 \mathrm{c}}$

Following the general procedure (addition time: $15 \mathrm{~min}$., benzene as solvent and t-butyl thiol as trapping reagent), flash chromatography (n-hexane:ethyl/acetate $=9 / 1)$ gave $\mathbf{7 a}(90 \mathrm{mg}, 60 \%)$ as a white crystalline material together with $\underline{7 b}(38 \mathrm{mg}, 15 \%)$.

7a: ${ }^{1} \mathrm{H}-\mathrm{NMR}\left(400 \mathrm{MHz}, \mathrm{CDCl}_{3}\right): \delta 7.38\left(\mathrm{dd}, \mathrm{J}_{4,5}=5.7 \mathrm{~Hz}, 1 \mathrm{H}, \mathrm{H}_{5}\right), 5.95\left(\mathrm{~m}, 2 \mathrm{H}, \mathrm{H}_{4}, \mathrm{H}_{8}\right.$ or $\left.\mathrm{H}_{9}\right), 5.78(\mathrm{dd}$, $\mathrm{J}_{8.9}=5.6 \mathrm{~Hz}, \mathrm{~J}_{1,9}$ resp. $\mathrm{J}_{7,8}=2.9 \mathrm{~Hz}, 1 \mathrm{H}, \mathrm{H}_{8}$ or $\left.\mathrm{H}_{9}\right), 3.42\left(\mathrm{~m}, 1 \mathrm{H}, \mathrm{H}_{6}\right), 3.22$ and $2.97\left(2 \mathrm{xbs}, 2 \mathrm{H}, \mathrm{H}_{1}\right.$ and $\left.\mathrm{H}_{7}\right)$, $2.80\left(\mathrm{dd}, \mathrm{J}_{1,2}=\mathrm{J}_{2,6}=5.1 \mathrm{~Hz}, 1 \mathrm{H}, \mathrm{H}_{2}\right), 1.76 \mathrm{~A}$ of $\mathrm{AB}\left(\mathrm{d}, \mathrm{J}_{10 \mathrm{a}, 10 \mathrm{~s}}=8.4 \mathrm{~Hz}, 1 \mathrm{H}, \mathrm{H}_{10 \mathrm{a}}\right.$ or $\left.\mathrm{H}_{10 \mathrm{~s}}\right), 1.62 \mathrm{~B}$ of $\mathrm{AB}(\mathrm{d}$, $\mathrm{J}_{10 \mathrm{a}, 10 \mathrm{~s}}=8.4 \mathrm{~Hz}, 1 \mathrm{H}, \mathrm{H}_{10 \mathrm{a}}$ or $\mathrm{H}_{10 \mathrm{~s}}$ ).

\section{6-Pyridylthio-endo-tricyclo[5.2.1.0 2,6]deca-4,8-dien-3-one 7b}

Following the general procedure (addition time: $15 \mathrm{~min}$., benzene as solvent), flash chromatography (n-hexane/ethyl acetate $=1 / 1)$ gave $\underline{\mathbf{7 b}}(230 \mathrm{mg}, 90 \%)$ as an oil.

7b: ${ }^{1} \mathrm{H}-\mathrm{NMR}\left(400 \mathrm{MHz}, \mathrm{CDCl}_{3}\right): \delta 8.45,7.50,7.22$ and $7.04(\mathrm{~m}, 4 \mathrm{H}, \mathrm{Py}-\mathrm{H}), 7.83\left(\mathrm{~d}, \mathrm{~J}_{4,5}=5.6 \mathrm{~Hz}, 1 \mathrm{H}, \mathrm{H}_{5}\right.$ ), 6.05-5.99 (m, $2 \mathrm{H}, \mathrm{H}_{8}$ and $\left.\mathrm{H}_{9}\right), 5.91\left(\mathrm{~d}, \mathrm{~J}_{4,5}=5.6 \mathrm{~Hz}, 1 \mathrm{H}, \mathrm{H}_{4}\right), 3.40$ and $3.32\left(2 \mathrm{x} \mathrm{brs}, 2 \mathrm{H}, \mathrm{H}_{1}\right.$ and $\left.\mathrm{H}_{7}\right), 3.00$ $\left(\mathrm{d}, \mathrm{J}_{1,2}=4.6 \mathrm{~Hz}, \mathrm{IH}, \mathrm{H}_{2}\right), 2.50 \mathrm{~A}$ of $\mathrm{AB}\left(\mathrm{d}, \mathrm{J}_{10 \mathrm{a}, 10 \mathrm{~s}}=8.9 \mathrm{~Hz}, 1 \mathrm{H}, \mathrm{H}_{10 \mathrm{~s}}\right), 1.86 \mathrm{~B}$ of $\mathrm{AB}\left(\mathrm{d}, \mathrm{J}_{10 \mathrm{a}, 10 \mathrm{~s}}=9.0 \mathrm{~Hz}, 1 \mathrm{H}\right.$, $\mathrm{H}_{10 \mathrm{a}}$ ). IR $\left(\mathrm{CH}_{2} \mathrm{Cl}_{2}\right)$ : v 3100-3020 (C-H, unsat.), 3010-2820 (C-H, sat.), $1700(\mathrm{C}=\mathrm{O}), 1575$ (C=C, conj.) $\mathrm{cm}^{-1}$. Cl/MS: m/e (\%) $256\left(100, \mathrm{M}^{+}+1\right), 228\left(25, \mathrm{M}^{+}-\mathrm{CO}\right), 190\left(38, \mathrm{M}^{+}-\mathrm{C}_{5} \mathrm{H}_{6}\right), 161\left(35, \mathrm{M}^{+}-\mathrm{C}_{5} \mathrm{H}_{6}-\mathrm{CO}\right)$, $145\left(24, \mathrm{M}^{+}-\mathrm{SPy}\right), 112\left(92, \mathrm{SPy}^{+}+1\right), 66\left(7, \mathrm{C}_{5} \mathrm{H}_{6}{ }^{+}\right)$. El/HRMS m/e: 256.0796 [calc.for $\mathrm{C}_{15} \mathrm{H}_{13} \mathrm{NOS}\left(\mathrm{M}^{+}\right)$: 256.0795].

\section{6-Chloro-endo-tricyclo[5.2.1.0.6 $0^{2,6}$ deca-4,8-dien-3-one 7c}

Following the general procedure (addition time: $30 \mathrm{~min}$., carbon tetrachloride as solvent and trapping reagent), flash chromatography ( $\mathrm{n}$-hexane/ethyl acetate $=9 / 1)$ gave $\underline{7 \mathrm{c}}(\underline{25} \mathrm{mg}, 14 \%)$ and $\underline{7 b}(180 \mathrm{mg}$, $70 \%)$.

7c: ${ }^{1} \mathrm{H}-\mathrm{NMR}\left(400 \mathrm{MHz}, \mathrm{CDCl}_{3}\right): \delta 7.30\left(\mathrm{~d}, \mathrm{~J}_{4,5}=5.6 \mathrm{~Hz}, 1 \mathrm{H}, \mathrm{H}_{5}\right), 6.02-5.96\left(\mathrm{~m}, 3 \mathrm{H}, \mathrm{H}_{4}, \mathrm{H}_{8}\right.$ and $\left.\mathrm{H}_{9}\right), 3.32$ and $3.10\left(2 \mathrm{x}\right.$ bs, $2 \mathrm{H}, \mathrm{H}_{1}$ and $\left.\mathrm{H}_{7}\right), 3.10\left(\mathrm{~d}, \mathrm{~J}_{1,2}=4.7 \mathrm{~Hz}, 1 \mathrm{H}, \mathrm{H}_{2}\right), 2.38 \mathrm{~A}$ of $\mathrm{AB}\left(\mathrm{d}, \mathrm{J}_{10 \mathrm{a}, 10 \mathrm{~s}}=9.0 \mathrm{~Hz}, 1 \mathrm{H}\right.$, $\left.\mathrm{H}_{10 \mathrm{~s}}\right), 2.00 \mathrm{~B}$ of $\mathrm{AB}\left(\mathrm{d}, \mathrm{J}_{10 \mathrm{a}, 10 \mathrm{~s}}=9.0 \mathrm{~Hz}, 1 \mathrm{H}, \mathrm{H}_{10 \mathrm{a}}\right)$. IR $\left(\mathrm{CH}_{2} \mathrm{Cl}_{2}\right):$ v 3100-3020 (C-H, unsat.), 3010-2820 (C-H, sat.), $1705(\mathrm{C}=\mathrm{O}), 1580\left(\mathrm{C}=\mathrm{C}, \mathrm{conj}\right.$.) $\mathrm{cm}^{-1}$. CI/MS: m/e (\%) $182\left(6, \mathrm{M}^{+}+1\right), 180\left(18, \mathrm{M}^{+}\right), 145(21$,

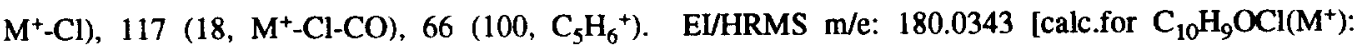
$180.0342]$.

\section{An improved procedure for the preparation of chloride $7 \mathrm{c}$}

The reaction was carried out as above but now without irradiation. (The reaction vessel was covered with aluminium foil). After adding the acid chloride, chlorine t-butyoxide $(0.5 \mathrm{ml})$ in $\mathrm{CCl}_{4}(1 \mathrm{ml})$ was added immediately. The stirring was continued for $20 \mathrm{~min}$. at room temp. The yield of $\underline{7 c}$ was improved to $-30 \%$ (55 mg). 


\section{6-Bromo-endo-tricyclo[5.2.1.0 2.0 ldeca-4,8-dien-3-one 7d}

Following the general procedure (enantiopure 6: $[\alpha]_{D}{ }^{25}=-84.3^{\circ}, c=0.65, \mathrm{CH}_{3} \mathrm{OH}$; addition time: 15 minutes, bromotrichloromethane as solvent and trapping reagent), flash chromatography (n-hexane/ethyl acetate $=9 / 1$ ) gave $150 \mathrm{mg}(67 \%)$ white crystalline bromide $\underline{7 \mathrm{~d}}$ and $155 \mathrm{mg}$ of a mixture of bromide $\underline{7 \mathrm{~d}}$ and pyridyl sulfide $\underline{\mathbf{7 b}}$ (containing $38 \%$ bromide $\underline{\mathbf{7 d}}$ acording to $\mathrm{GC}$ ). (Complete isolation of $\underline{\mathbf{7 d}}$ is possible by repeating flash chromatography and recrystallization). So, the total yield of bromide $\mathbf{7 d}$ is $\mathbf{9 3 \%}$.

7d: m.p.: $>80^{\circ} \mathrm{C}$, decomposition (n-hexane), $[\alpha]_{\mathrm{D}}{ }^{25}=-222^{\circ}\left(\mathrm{c}=0,69, \mathrm{CH}_{3} \mathrm{OH}\right) .{ }^{1} \mathrm{H}-\mathrm{NMR}(400 \mathrm{MHz}$, $\left.\mathrm{CDCl}_{3}\right): \delta 7.41\left(\mathrm{~d}, \mathrm{~J}_{4,5}=5.6 \mathrm{~Hz}, 1 \mathrm{H}, \mathrm{H}_{5}\right), 6.00 \mathrm{~A}$ of $\mathrm{AB}\left(\mathrm{dd}, \mathrm{J}_{8,9}=5.6 \mathrm{~Hz}, \mathrm{~J}_{1,9}\right.$ resp. $\mathrm{J}_{7,8}=2.8 \mathrm{~Hz}, 1 \mathrm{H}, \mathrm{H}_{8}$ or $\mathrm{H}_{9}$ ), $5.95 \mathrm{~B}$ of $\mathrm{AB}\left(\mathrm{dd}, \mathrm{J}_{8,9}=5.6 \mathrm{~Hz}, \mathrm{~J}_{1,9}\right.$ resp. $\mathrm{J}_{7,8}=3.2 \mathrm{~Hz}, 1 \mathrm{H}, \mathrm{H}_{8}$ or $\left.\mathrm{H}_{9}\right), 5.94\left(\mathrm{~d}, \mathrm{~J}_{4,5}=5.6 \mathrm{~Hz}, 1 \mathrm{H}, \mathrm{H}_{4}\right.$ ), 3.31 and $3.25\left(2 \mathrm{x}\right.$ brs, $2 \mathrm{H}, \mathrm{H}_{1}$ and $\left.\mathrm{H}_{7}\right), 3.21\left(\mathrm{~d}, \mathrm{~J}_{1,2}=4.6 \mathrm{~Hz}, 1 \mathrm{H}, \mathrm{H}_{2}\right), 2.44 \mathrm{~A}$ of $\mathrm{AB}\left(\mathrm{d}, \mathrm{J}_{10 \mathrm{a}, 10 \mathrm{~s}}=9.0 \mathrm{~Hz}, 1 \mathrm{H}\right.$, $\left.\mathrm{H}_{10 \mathrm{~s}}\right), 2.04 \mathrm{~B}$ of $\mathrm{AB}\left(\mathrm{dt}, \mathrm{J}_{10 \mathrm{a}, 10 \mathrm{~s}}=9.0 \mathrm{~Hz}, \mathrm{~J}_{10 \mathrm{a}, 1}=\mathrm{J}_{10 \mathrm{a}, 7}=1.6 \mathrm{~Hz}, 1 \mathrm{H}, \mathrm{H}_{10 \mathrm{a}}\right) . \mathrm{IR}\left(\mathrm{CH}_{2} \mathrm{Cl}_{2}\right): v 3100-3020(\mathrm{C}-\mathrm{H}$, unsat.), 3010-2820 (C-H, sat.), $1700(\mathrm{C}=\mathrm{O}), 1575$ (C=C, conj.) $\mathrm{cm}^{-1}$. CI/MS: $\mathrm{m} / \mathrm{e}(\%) 227\left(9, \mathrm{M}^{+}+2\right), 225$ $\left(10, \mathrm{M}^{+}\right), 145\left(100, \mathrm{M}^{+}-\mathrm{Br}\right), 117\left(55, \mathrm{M}^{+}-\mathrm{Br}-\mathrm{CO}\right), 66\left(100, \mathrm{C}_{5} \mathrm{H}_{6}{ }^{+}\right)$. Found: C 52.72, H 3.94 (calc.for $\mathrm{C}_{10} \mathrm{H}_{9} \mathrm{OBr}: \mathrm{C}$ 53.36, $\left.\mathrm{H} 4.03\right)$.

\section{6-lodo-endo-tricyclo/5.2.1.0 $0^{2,6}$ ldeca-4,8-dien-3-one 7e}

Following the general procedure [addition time: 15 minutes, toluene as solvent and iodoform (800 mg, 2 eq.) as trapping reagent], flash chromatography (n-hexane:ethyl acetate $=9: 1)$ gave $\underline{7 e}(170 \mathrm{mg}, 62.5 \%)$ as a white crystalline material. An analytical sample was obtained by crystallization.

7e: m.p.: 83.5-85.5 ${ }^{\circ} \mathrm{C}$ (diisopropylether). ${ }^{1} \mathrm{H}-\mathrm{NMR}\left(400 \mathrm{MHz}, \mathrm{CDCl}_{3}\right): \delta 7.55\left(\mathrm{~d}, \mathrm{~J}_{4,5}=5.6 \mathrm{~Hz}, 1 \mathrm{H}, \mathrm{H}_{5}\right)$, $5.97 \mathrm{~A}$ of $\mathrm{AB}\left(\mathrm{dd}, \mathrm{J}_{8,9}=5.5 \mathrm{~Hz}, \mathrm{~J}_{1,9}\right.$ resp. $\mathrm{J}_{7,8}=2.8 \mathrm{~Hz}, 1 \mathrm{H}, \mathrm{H}_{8}$ or $\mathrm{H}_{9}$ ), $5.89 \mathrm{~B}$ of $\mathrm{AB}\left(\mathrm{dd}, \mathrm{J}_{8,9}=5.5 \mathrm{~Hz}, \mathrm{~J}_{1,9}\right.$ resp. $\mathrm{J}_{7,8}=3.1 \mathrm{~Hz}, 1 \mathrm{H}, \mathrm{H}_{8}$ or $\left.\mathrm{H}_{9}\right), 5.83\left(\mathrm{~d}, \mathrm{~J}_{4,5}=5.6 \mathrm{~Hz}, 1 \mathrm{H}, \mathrm{H}_{4}\right), 3.39$ and $3.27\left(2 \mathrm{x} \mathrm{brs}, 2 \mathrm{H}, \mathrm{H}_{1}\right.$ and $\left.\mathrm{H}_{7}\right), 3.24$ $\left(\mathrm{d}, \mathrm{J}_{1,2}=4.6 \mathrm{~Hz}, 1 \mathrm{H}, \mathrm{H}_{2}\right), 2.49 \mathrm{~A}$ of $\mathrm{AB}\left(\mathrm{d}, \mathrm{J}_{10 \mathrm{a}, 10 \mathrm{~s}}=9.0 \mathrm{~Hz}, 1 \mathrm{H}, \mathrm{H}_{10 \mathrm{~s}}\right), 2.07 \mathrm{~B}$ of $\mathrm{AB}\left(\mathrm{dt}, \mathrm{J}_{10 \mathrm{a}, 10 \mathrm{~s}}=9.0 \mathrm{~Hz}\right.$, $\left.\mathrm{J}_{10 \mathrm{a}, 1}=\mathrm{J}_{10 \mathrm{a}, 7}=1.6 \mathrm{~Hz}, 1 \mathrm{H}, \mathrm{H}_{10 \mathrm{a}}\right)$. IR $\left(\mathrm{CH}_{2} \mathrm{Cl}_{2}\right):$ v 3100-3020 (C-H, unsat.), 3010-2820 (C-H, sat.), 1700 $(\mathrm{C}=\mathrm{O}), 1570\left(\mathrm{C}=\mathrm{C}\right.$, conj.) $\mathrm{cm}^{-1}$. CI/MS: $\mathrm{m} / \mathrm{e}(\%) 273\left(3, \mathrm{M}^{+}+1\right), 145(100,-\mathrm{I}), 117(17,-\mathrm{I}-\mathrm{CO}), 79\left(9, \mathrm{I}^{+}\right)$, $66\left(19, \mathrm{C}_{5} \mathrm{H}_{6}{ }^{+}\right)$. EI/HRMS m/e: 272.9776 [calc.for $\mathrm{C}_{10} \mathrm{H}_{9} \mathrm{OI}\left(\mathrm{M}^{+}+1\right): 272.9776$ ].

\section{6-Methylsulfanyl-endo-tricyclo/5.2.1.0 $\left.0^{2,6}\right]$ deca-4,8-dien-3-one $7 \mathrm{f}$}

Following the general procedure (addition time: $>30 \mathrm{~min}$., dimethyl disulfide as solvent and trapping reagent), flash chromatography (n-hexane/ethyl $=9 / 1)$ gave $\underline{\text { ff }}(90 \mathrm{mg}, 22 \%)$ as a colourless oil.

7f: $7.23 \mathrm{~A}$ of $\mathrm{AB}\left(\mathrm{d}, \mathrm{J}_{4,5}=5.6 \mathrm{~Hz}, 1 \mathrm{H}, \mathrm{H}_{5}\right), 6.01-5.97\left(\mathrm{~m}, 2 \mathrm{H}, \mathrm{H}_{8}\right.$ and $\left.\mathrm{H}_{9}\right), 5.95 \mathrm{~B}$ of $\mathrm{AB}\left(\mathrm{d}, \mathrm{J}_{4,5}=5.6 \mathrm{~Hz}, 1 \mathrm{H}\right.$, $\left.\mathrm{H}_{4}\right), 3.32$ and $2.84\left(2 \mathrm{x}\right.$ brs, $2 \mathrm{H}, \mathrm{H}_{1}$ and $\left.\mathrm{H}_{7}\right), 2.81\left(\mathrm{~d}, \mathrm{~J}_{1,2}=4.6 \mathrm{~Hz}, 1 \mathrm{H}, \mathrm{H}_{2}\right), 2.34 \mathrm{~A}$ of $\mathrm{AB}\left(\mathrm{d}, \mathrm{J}_{10 \mathrm{a}, 10 \mathrm{~s}}=8.7 \mathrm{~Hz}\right.$, $\left.1 \mathrm{H}, \mathrm{H}_{10 \mathrm{~s}}\right), 1.85 \mathrm{~B}$ of $\mathrm{AB}\left(\mathrm{dt}, \mathrm{J}_{10 \mathrm{a}, 10 \mathrm{~s}}=8.7 \mathrm{~Hz}, \mathrm{~J}_{10 \mathrm{a}, 1}=\mathrm{J}_{10 \mathrm{a}, 7}=1.6 \mathrm{~Hz}, 1 \mathrm{H}, \mathrm{H}_{10 \mathrm{a}}\right)$. IR $\left(\mathrm{CH}_{2} \mathrm{Cl}_{2}\right): v 3100-3020$ (C-H, unsat.), 3010-2820 (C-H, sat.), 1700 (C=O), 1570 (C=C, conj.) $\mathrm{cm}^{-1}$. El/MS: m/e (\%) $192\left(16, \mathrm{M}^{+}\right)$, $164\left(79, \mathrm{M}^{+}-\mathrm{CO}\right), 126\left(86, \mathrm{M}^{+}-\mathrm{C}_{5} \mathrm{H}_{6}\right), 144\left(57, \mathrm{M}^{+}-\mathrm{CH}_{3} \mathrm{SH}\right), 98\left(28, \mathrm{M}^{+}-\mathrm{C}_{5} \mathrm{H}_{6}-\mathrm{CO}\right), 117(62$, $\left.\mathrm{M}^{+}-\mathrm{CH}_{3} \mathrm{~S}-\mathrm{CO}\right), 66\left(100, \mathrm{C}_{5} \mathrm{H}_{6}{ }^{+}\right.$). EI/HRMS m/e: 192.0608 [calc.for $\mathrm{C}_{11} \mathrm{H}_{12} \mathrm{OS}\left(\mathrm{M}^{+}\right)$: 192.0609].

\section{6-Phenylsulfanyl-endo-tricyclo[5.2.1.0 $\left.0^{2,6}\right] \mathrm{dec}$-8-en-3-one $7 \mathrm{~g}$}

Following the general procedure (addition time: 15 minutes, toluene as solvent and diphenyl disulfide (10 eq.) as trapping reagent), flash chromatography (n-hexane:ethyl $=9: 1)$ gave $7 \mathrm{~g}(105 \mathrm{mg}, 42 \%)$ as a white solid.

7g: m.p.: $58{ }^{\circ} \mathrm{C} .{ }^{1} \mathrm{H}-\mathrm{NMR}\left(400 \mathrm{MHz}, \mathrm{CDCl}_{3}\right): \delta 7.50$ and 7.29-7.40 (m, 5H, Ph-H), 7.26 A of AB (d, 
$\left.\mathrm{J}_{4,5}=5.6 \mathrm{~Hz}, 1 \mathrm{H}, \mathrm{H}_{5}\right), 5.97 \mathrm{~A}$ of $\mathrm{AB}\left(\mathrm{dd}, \mathrm{J}_{8,9}=5.5 \mathrm{~Hz}, \mathrm{~J}_{1,9}\right.$ resp. $\mathrm{J}_{7,8}=2.9 \mathrm{~Hz}, 1 \mathrm{H}, \mathrm{H}_{8}$ or $\mathrm{H}_{9}$ ), $5.92 \mathrm{~B}$ of $\mathrm{AB}$ (dd, $\mathrm{J}_{8,9}=5.5 \mathrm{~Hz}, \mathrm{~J}_{1,9}$ resp. $\mathrm{J}_{7.8}=3.0 \mathrm{~Hz}, 1 \mathrm{H}, \mathrm{H}_{8}$ or $\mathrm{H}_{9}$ ), $5.80 \mathrm{~B}$ of $\mathrm{AB}\left(\mathrm{d}, \mathrm{J}_{4.5}=5.6 \mathrm{~Hz}, 1 \mathrm{H}, \mathrm{H}_{4}\right), 3.31$ and 2.94 ( $2 \mathrm{x}$ brs, $2 \mathrm{H}, \mathrm{H}_{1}$ and $\mathrm{H}_{7}$ ), $2.80\left(\mathrm{~d}, \mathrm{~J}_{1,2}=4.6 \mathrm{~Hz}, 1 \mathrm{H}, \mathrm{H}_{2}\right), 2.49 \mathrm{~A}$ of $\mathrm{AB}\left(\mathrm{d}, \mathrm{J}_{10 \mathrm{a}, 10 \mathrm{~s}}=8.7 \mathrm{~Hz}, 1 \mathrm{H}, \mathrm{H}_{10 \mathrm{~s}}\right), 1.90 \mathrm{~B}$ of $\mathrm{AB}$ (dt, $\left.\mathrm{J}_{10 \mathrm{a}, 10 \mathrm{~s}}=8.7 \mathrm{~Hz}, \mathrm{~J}_{10 \mathrm{a}, 1}=\mathrm{J}_{10 \mathrm{a}, 7}=1.6 \mathrm{~Hz}, 1 \mathrm{H}, \mathrm{H}_{10 \mathrm{a}}\right)$. IR $\left(\mathrm{CH}_{2} \mathrm{Cl}_{2}\right): v 3100-3020(\mathrm{C}-\mathrm{H}$, unsat.), 3010-2820 (C-H, sat.), $1700(\mathrm{C}=\mathrm{O}), 1570\left(\mathrm{C}=\mathrm{C}\right.$, conj.) $\mathrm{cm}^{-1}$. CI/MS: $\mathrm{m} / \mathrm{e}(\%) 254\left(22, \mathrm{M}^{+}\right), 226(100$, $\left.\mathrm{M}^{+}-\mathrm{CO}\right), 188\left(41, \mathrm{M}^{+}-\mathrm{C}_{5} \mathrm{H}_{6}\right), 160\left(37, \mathrm{M}^{+}-\mathrm{C}_{5} \mathrm{H}_{6}-\mathrm{CO}\right), 145$ (74, $\left.\mathrm{M}^{+}-\mathrm{SPh}\right), 117$ (71, $\left.\mathrm{M}^{+}-\mathrm{SPh}-\mathrm{CO}\right), 66(11$, $\mathrm{C}_{5} \mathrm{H}_{6}{ }^{+}$). EI/HRMS m/e: 254.0765 [calc.for $\mathrm{C}_{16} \mathrm{H}_{14} \mathrm{OS}\left(\mathrm{M}^{+}\right)$: 254.0765 ].

\section{6-Phenylselenyl-endo-tricyclo[5.2.1.0 $\left.0^{2,6}\right]$ deca-4,8-dien-3-one $7 \mathrm{~h}$}

Following the general procedure [addition time: 15 minutes, toluene as solvent and diphenyl diselenide (2 eq.) as trapping reagent], flash chromatography (n-hexane:ethyl $=19: 1)$ gave $7 \mathrm{~h}$ ( $282 \mathrm{mg}, 94 \%$ ) as a white solid.

7h: m.p.: $69-71^{\circ} \mathrm{C}$ (10\% diisopropylether in n-hexane). ${ }^{1} \mathrm{H}-\mathrm{NMR}\left(400 \mathrm{MHz}, \mathrm{CDCl}_{3}\right.$ ): 87.60 and 7.40-7.25 $\left(\mathrm{m}, 6 \mathrm{H}, \mathrm{Ph}-\mathrm{H}\right.$ and $\left.\mathrm{H}_{5}\right), 5.94 \mathrm{~A}$ of $\mathrm{AB}\left(\mathrm{dd}, \mathrm{J}_{8,9}=5.5 \mathrm{~Hz}, \mathrm{~J}_{1,9}\right.$ resp. $\mathrm{J}_{7,8}=2.9 \mathrm{~Hz}, 1 \mathrm{H}, \mathrm{H}_{8}$ or $\mathrm{H}_{9}$ ), 5.89 B of AB (dd, $\mathrm{J}_{8,9}=5.5 \mathrm{~Hz}, \mathrm{~J}_{1,9}$ resp. $\mathrm{J}_{7,8}=3.0 \mathrm{~Hz}, 1 \mathrm{H}, \mathrm{H}_{8}$ or $\left.\mathrm{H}_{9}\right), 5.75\left(\mathrm{~d}, \mathrm{~J}_{4.5}=5.6 \mathrm{~Hz}, 1 \mathrm{H}, \mathrm{H}_{4}\right), 3.31$ and $2.98(2 \mathrm{x}$ brs, $2 \mathrm{H}, \mathrm{H}_{1}$ and $\left.\mathrm{H}_{7}\right), 2.83\left(\mathrm{~d}, \mathrm{~J}_{1,2}=4.6 \mathrm{~Hz}, 1 \mathrm{H}, \mathrm{H}_{2}\right), 2.47 \mathrm{~A}$ of $\mathrm{AB}\left(\mathrm{d}, \mathrm{J}_{10 \mathrm{a}, 10 \mathrm{~s}}=8.7 \mathrm{~Hz}, 1 \mathrm{H}, \mathrm{H}_{10 \mathrm{~s}}\right), 1.92 \mathrm{~B}$ of AB (dt, $\left.\mathrm{J}_{10 \mathrm{a}, 10 \mathrm{~s}}=8.7 \mathrm{~Hz}, \mathrm{~J}_{10 \mathrm{a}, \mathrm{l}}=\mathrm{J}_{10 \mathrm{a}, 7}=1.6 \mathrm{~Hz}, 1 \mathrm{H}, \mathrm{H}_{10 \mathrm{a}}\right)$. IR $\left(\mathrm{CH}_{2} \mathrm{Cl}_{2}\right)$ : v 3100-3020 (C-H, unsat.), 3010-2820 (C-H, sat.), $1695(\mathrm{C}=\mathrm{O}), 1570\left(\mathrm{C}=\mathrm{C}\right.$, conj.) $\mathrm{cm}^{-1}$. El/MS: m/e (\%) $302\left(17, \mathrm{M}^{+}\right), 274\left(49, \mathrm{M}^{+}-\mathrm{CO}\right), 157$ $\left(17, \mathrm{SePh}^{+}\right), 145\left(98, \mathrm{M}^{+}-\mathrm{SePh}\right), 117\left(100, \mathrm{M}^{+}-\mathrm{SePh}-\mathrm{CO}\right), 79\left(84, \mathrm{M}^{+}-\mathrm{C}_{5} \mathrm{H}_{6}-\mathrm{SePh}\right), 66\left(17, \mathrm{C}_{5} \mathrm{H}_{6}{ }^{+}\right)$. EI/HRMS m/e: $302.0200 \pm 0.0009$ [calc.for $\mathrm{C}_{16} \mathrm{H}_{14} \mathrm{OSe}\left(\mathrm{M}^{+}\right)$: 302.0210 ].

6-Hydroxy-endo-tricyclo/5.2.1.0 $\left.0^{2,6}\right]$ deca-4,8-dien-3-one $7 \mathbf{i}$ and 5-oxo-endo-tricyclo $\left[5.2 .1 .0^{2,6}\right]$ deca-4,8dien-2-carbothioic acid S-phenyl ester 14

The acid chloride of 6 (1 mmole) in dichloromethane $(5 \mathrm{ml})$ was added (5 minutes) to a dried, stirred suspension of $\mathrm{N}$-hydroxypyridin-2-thione sodium salt $(1.2 \mathrm{mmole})$ in dichloromethane $(5 \mathrm{ml})$ at room temp. under an air atmosphere. The reaction vessel was covered with aluminium foil. After completion of the addition ( $\mathrm{PhS})_{3} \mathrm{Sb}(900 \mathrm{mg}, 2 \mathrm{mmole}$ ) in dichloromethane was added and stirring continued for $10 \mathrm{~min}$. at room temp. while protecting from light!. Then water $(0.5 \mathrm{ml})$ was added and the aluminum foil removed. The mixture was stirred at room temp. for another $2 \mathrm{hrs.} \mathrm{Solid} \mathrm{material} \mathrm{was} \mathrm{removed} \mathrm{by} \mathrm{filtering}$ and the liquid layer concentrated in vacuo. The crude product was purified by flash chromatography (n-hexane/ethyl acetate $=4 / 1)$ on silica gel to give $\underline{7 \mathbf{i}}(65 \mathrm{mg}, 40 \%)$ and $\underline{14}(70 \mathrm{mg}, 25 \%)$. An analytical sample was obtained by crystallization.

7i: m.p. $73-75^{\circ} \mathrm{C}$ (diisopropyl ether). ${ }^{1} \mathrm{H}-\mathrm{NMR}\left(400 \mathrm{MHz}, \mathrm{CDCl}_{3}\right): \delta 7.28\left(\mathrm{~d}, \mathrm{~J}_{4,5}=5.7 \mathrm{~Hz}, 1 \mathrm{H}, \mathrm{H}_{5}\right.$ ), $6.00 \mathrm{~A}$ of $A B\left(d d, J_{8,9}=5.6 \mathrm{~Hz}, \mathrm{~J}_{1,9}\right.$ resp. $\mathrm{J}_{7,8}=3.1 \mathrm{~Hz}, 1 \mathrm{H}, \mathrm{H}_{8}$ or $\mathrm{H}_{9}$ ), $5.97 \mathrm{~B}$ of $\mathrm{AB}\left(\mathrm{dd}, \mathrm{J}_{8,9}=5.6 \mathrm{~Hz}, \mathrm{~J}_{1,9}\right.$ resp. $\mathrm{J}_{7,8}=2.8 \mathrm{~Hz}, 1 \mathrm{H}, \mathrm{H}_{8}$ or $\left.\mathrm{H}_{9}\right), 5.95\left(\mathrm{~d}, \mathrm{~J}_{4,5}=5.7 \mathrm{~Hz}, 1 \mathrm{H}, \mathrm{H}_{4}\right), 3.24$ and $2.80\left(2 \mathrm{x}\right.$ brs, $2 \mathrm{H}, \mathrm{H}_{1}$ and $\left.\mathrm{H}_{7}\right), 2.66(\mathrm{~d}$, $\left.\mathrm{J}_{1,2}=4.5 \mathrm{~Hz}, 1 \mathrm{H}, \mathrm{H}_{2}\right), 2.71(\mathrm{~s}, 1 \mathrm{H}, \mathrm{OH}), 2.30 \mathrm{~A}$ of $\mathrm{AB}\left(\mathrm{d}, \mathrm{J}_{10 \mathrm{a}, 10 \mathrm{~s}}=8.7 \mathrm{~Hz}, 1 \mathrm{H}, \mathrm{H}_{10 \mathrm{~s}}\right), 1.95 \mathrm{~B}$ of $\mathrm{AB}(\mathrm{dt}$, $\left.\mathrm{J}_{10 \mathrm{a}, 10 \mathrm{~s}}=8.7 \mathrm{~Hz}, \mathrm{~J}_{10 \mathrm{a}, 1}=\mathrm{J}_{10 \mathrm{a}, 7}=1.5 \mathrm{~Hz}, 1 \mathrm{H}, \mathrm{H}_{10 \mathrm{a}}\right)$. IR $\left(\mathrm{CH}_{2} \mathrm{Cl}_{2}\right):$ v 3600-3500 (free $\mathrm{OH}$ ), 3600-3100 (H-bonded $\mathrm{OH}$ ), 3100-3020 (C-H, unsat.), 3010-2820 (C-H, sat.), $1700(\mathrm{C}=\mathrm{O}), 1570(\mathrm{C}=\mathrm{C}$, conj.), 1030 (C-O) $\mathrm{cm}^{-1} . \mathrm{Cl} / \mathrm{MS}: \mathrm{m} / \mathrm{e}(\%) 163\left(100, \mathrm{M}^{+}+1\right), 145\left(36,-\mathrm{H}_{2} \mathrm{O}\right), 134\left(76, \mathrm{M}^{+}-\mathrm{CO}\right), 97\left(45, \mathrm{M}^{+}+1-\mathrm{C}_{5} \mathrm{H}_{6}\right), 66$ $\left(94, \mathrm{C}_{5} \mathrm{H}_{6}{ }^{+}\right)$. El/HRMS m/e: 162.0680 [calc.for $\mathrm{C}_{10} \mathrm{H}_{10} \mathrm{O}_{2}\left(\mathrm{M}^{+}\right)$: 162.0681], 163.0759 [calc.for $\mathrm{C}_{10} \mathrm{H}_{11} \mathrm{O}_{2}\left(\mathrm{M}^{+}+1\right): 163.0759$ ]. 
14: m.p.: 77.5-79 ${ }^{\circ} \mathrm{C}$ (diisopropylether). ${ }^{1} \mathrm{H}-\mathrm{NMR}\left(400 \mathrm{MHz}, \mathrm{CDCl}_{3}\right): \delta 7.48\left(\mathrm{~d}, \mathrm{~J}_{3,4}=5.7 \mathrm{~Hz}, 1 \mathrm{H}, \mathrm{H}_{3}\right)$, 7.45-7.38 (m, $5 \mathrm{H}, \mathrm{Ph}-\mathrm{H}), 6.09\left(\mathrm{~d}, \mathrm{~J}_{3,4}=5.7 \mathrm{~Hz}, 1 \mathrm{H}, \mathrm{H}_{4}\right), 6.07 \mathrm{~A}$ of $\mathrm{AB}$ (dd, $\mathrm{J}_{8,9}=5.5 \mathrm{~Hz}, \mathrm{~J}_{1,9}$ resp. $\mathrm{J}_{7,8}=2.7$ $\mathrm{Hz}, 1 \mathrm{H}, \mathrm{H}_{8}$ or $\left.\mathrm{H}_{9}\right), 6.00 \mathrm{~B}$ of $\mathrm{AB}\left(\mathrm{dd}, \mathrm{J}_{8,9}=5.5 \mathrm{~Hz}, \mathrm{~J}_{1,9}\right.$ resp. $\mathrm{J}_{7,8}=3.1 \mathrm{~Hz}, 1 \mathrm{H}, \mathrm{H}_{8}$ or $\left.\mathrm{H}_{9}\right), 3.38\left(\mathrm{~d}, \mathrm{~J}_{6,7}=4.7\right.$ $\left.\mathrm{Hz}, 1 \mathrm{H}, \mathrm{H}_{6}\right), 3.36$ and $3.33\left(2 \mathrm{x}\right.$ bs, $2 \mathrm{H}, \mathrm{H}_{1}$ and $\left.\mathrm{H}_{7}\right), 1.99 \mathrm{~A}$ of $\mathrm{AB}\left(\mathrm{d}, \mathrm{J}_{10 \mathrm{a}, 10 \mathrm{~s}}=9.0 \mathrm{~Hz}, 1 \mathrm{H}, \mathrm{H}_{10 \mathrm{~s}}\right), 1.79 \mathrm{~B}$ of $\mathrm{AB}\left(\mathrm{d}, \mathrm{J}_{10 \mathrm{a}, 10 \mathrm{~s}}=9.0 \mathrm{~Hz}, 1 \mathrm{H}, \mathrm{H}_{10 \mathrm{a}}\right)$. IR $\left(\mathrm{CH}_{2} \mathrm{Cl}_{2}\right)$ : v 3100-3020 (C-H, unsat.), 3010-2820 (C-H, sat.), 1700 $(\mathrm{C}=\mathrm{O}), 1580\left(\mathrm{C}=\mathrm{C}\right.$, conj.) $\mathrm{cm}^{-1}$. CI/MS: m/e (\%) $283\left(28, \mathrm{M}^{+}+1\right), 255(50,-\mathrm{CO}), 217\left(6, \mathrm{M}^{+}+1-\mathrm{C}_{5} \mathrm{H}_{6}\right)$, $173\left(86, \mathrm{M}^{+}-\mathrm{SPh}\right), 145\left(100, \mathrm{M}^{+}-\mathrm{COSPh}\right), 66\left(34, \mathrm{C}_{5} \mathrm{H}_{6}{ }^{+}\right)$. El/HRMS m/e: 283.0791 [calc.for $\mathrm{C}_{17} \mathrm{H}_{15} \mathrm{O}_{2} \mathrm{~S}\left(\mathrm{M}^{+}+1\right)$ : 283.0793]. Found: $\mathrm{C} 72.06$, H 4.95, S 11.40 (calc.for $\mathrm{C}_{17} \mathrm{H}_{14} \mathrm{O}_{2} \mathrm{~S}: \mathrm{C} 72.31, \mathrm{H} 5.00, \mathrm{~S}$ 11.36).

Pentacyclo[5.3.0.0 $\left.0^{2,5} \cdot 0^{3,9} \cdot 0^{4,8}\right]$ deca-10-one-2-carboxylic acid 17

A solution of ester 15 (1.5 g) in toluene $(140 \mathrm{ml})$ was irradiated for $5 \mathrm{hrs}$ using a high-pressure mercury arc and a Pyrex filter. Concentration in vacuo gave rather pure $\underline{16}$ as a oil.

16: ${ }^{1} \mathrm{H}-\mathrm{NMR}\left(400 \mathrm{MHz}, \mathrm{CDCl}_{3}\right): \delta 4.16$ and $4.11 \mathrm{AB} \times 2\left(2 \times \mathrm{d}_{\mathrm{a}, \mathrm{b}}=7.1 \mathrm{~Hz}, 2 \mathrm{H}, \mathrm{CH}_{2} \mathrm{CH}_{3}\right), 3.39,3.12$, $3.02,2.96,2.62$ and $2.52(6 \times \mathrm{m}, 7 \mathrm{H}), 1.93$ and $1.65 \mathrm{AB}$ system $\left(2 \times \mathrm{d}, \mathrm{J}_{10 \mathrm{a}, 10 \mathrm{~s}}=11.7 \mathrm{~Hz}, 1 \mathrm{H}, \mathrm{H}_{10}\right)$.

Above ester $\underline{\mathbf{1 6}}$ was dissolved in methanol/water $(25 \mathrm{ml}, 1: 1)$ containing sodium hydroxide $(10 \%)$ and stirred at room temp. for $2 \mathrm{hrs}$ to give a $\underline{17}(1.5 \mathrm{~g})$ as a white solid. Chromatography (a little amount of silica gel, $\mathrm{n}$-hexane/EtOAc $=1 / 1)$ gave pure $\underline{17}(1.12 \mathrm{~g}, 95 \%)$ as a white crystalline solid.

17: m.p.: 83-85 ${ }^{\circ} \mathrm{C} .{ }^{1} \mathrm{H}-\mathrm{NMR}\left(400 \mathrm{MHz}, \mathrm{CDCl}_{3}\right.$ ): $\delta 9.29$ (brs, $1 \mathrm{H}, \mathrm{COOH}$ ), 3.42, 3.17, 3.06, 2.97, 2.64 and $2.59\left(6 \times \mathrm{m}, 7 \mathrm{H}\right.$, all of tert.H), 1.94 and $1.68 \mathrm{ABx} 2\left(2 \times \mathrm{d}, \mathrm{J}_{\mathrm{a}, \mathrm{b}}=11.7 \mathrm{~Hz}, 2 \mathrm{H}, \mathrm{CH}_{2}\right),{ }^{13} \mathrm{C}-\mathrm{NMR}(100 \mathrm{MHz}$, $\mathrm{CDCl}_{3}$ ): $\delta$ 214.2/178.6/54.0 (quat.), 53.2/47.5/43.5 (tert.), 41.4 (sec.), 41.0/40.6/38.6/36.9 (tert.). IR $\left(\mathrm{CH}_{2} \mathrm{Cl}_{2}\right)$ : v 3500-2700 (COOH), 3010-2820 (C-H, sat.), 1760 and $1700(\mathrm{C}=\mathrm{O}) \mathrm{cm}^{-1}$. EL/MS: $\mathrm{m} / \mathrm{e}(\%) 190$ $\left(14, \mathrm{M}^{+}\right), 162\left(17, \mathrm{M}^{+}-\mathrm{CO}\right), 145\left(15, \mathrm{M}^{+}-\mathrm{COOH}\right), 117\left(100, \mathrm{M}^{+}-\mathrm{COOH}-\mathrm{CO}\right), 66\left(21, \mathrm{C}_{5} \mathrm{H}_{6}^{+}\right)$. EI/HRMS m/e: 190.0631 [calc.for $\mathrm{C}_{11} \mathrm{H}_{10} \mathrm{O}_{3}\left(\mathrm{M}^{+}\right)$: 190.0630 ].

\section{8-Bromo-pentacyclo $\left[5 \cdot 3 \cdot 0 \cdot 0^{2,5} \cdot 0^{3,9} \cdot 0^{4,8}\right]$ deca-6-one 18a}

Following the general procedure (addition time: 30 minutes, bromotrichloromethane as solvent and trapping reagent), flash chromatography (n-hexane/ethyl acetate $=9 / 1)$ gave a mixture $(310 \mathrm{mg})$ of $\underline{18 a}$ and the corresponding pyridyl sulfide. The yield of $\underline{18 a}$ is $87 \%$ (content of $\underline{18 a}$ is $63 \%$ by GC).

18a: ${ }^{1} \mathrm{H}-\mathrm{NMR}\left(90 \mathrm{MHz}, \mathrm{CDCl}_{3}\right): \delta 3.41,3.25,2.99$ and $2.60(\mathrm{~m}, 7 \mathrm{H}$, tert- $\mathrm{H}), 2.15$ and $1.61 \mathrm{AB}(2 \mathrm{x} \mathrm{d}$, $\mathrm{J}_{\mathrm{a}, \mathrm{b}}=11.7 \mathrm{~Hz}, 2 \mathrm{H}, \mathrm{CH}_{2}$ ). GC-EI/MS: m/e (\%) $226\left(2, \mathrm{M}^{+}+1\right), 224\left(2, \mathrm{M}^{+}-1\right), 198\left(13, \mathrm{M}^{+}+1-\mathrm{CO}\right), 196(13$, $\left.\mathrm{M}^{+}-1-\mathrm{CO}\right), 145\left(52, \mathrm{M}^{+}-\mathrm{Br}\right), 117\left(100, \mathrm{M}^{+}-\mathrm{Br}-\mathrm{CO}\right), 66\left(44, \mathrm{C}_{5} \mathrm{H}_{6}^{+}\right)$.

\section{8-Phenylselenyl-pentacyclol5.3.0.0.0 $\left.0^{2,5} \cdot 0^{3,9} \cdot 0^{4,8}\right]$ deca-6-one $18 \mathrm{~b}$}

Following the general procedure [addition time: 15 minutes, toluene as solvent and diphenyl selenide (470mg, $1.5 \mathrm{mmol}$ ) as trapping reagent], flash chromatography ( $\mathrm{n}$-hexane/EtOAc $=9 / 1$ ) gave a mixture (375mg) of $\underline{18 b}$ and the corresponding pyridyl sulfide. The yield of $\underline{18 b}$ is $94 \%$. Pure $\underline{18 b}$ was obtained by recrystallization.

18b: m.p.: 76-77.5 ${ }^{\circ} \mathrm{C}$ (ether). ${ }^{1} \mathrm{H}-\mathrm{NMR}\left(400 \mathrm{MHz}, \mathrm{CDCl}_{3}\right.$ ): $\delta{ }^{1} \mathrm{H}-\mathrm{NMR}\left(400 \mathrm{MHz}, \mathrm{CDCl}_{3}\right.$ ): $\delta 7.58$, 7.37-7.26 (m, 5H, Ph-H), 3.22, 3.08, 3.94, 2.56 and $2.32(5 \times \mathrm{m}, 7 \mathrm{H}), 1.76$ and $1.54 \mathrm{ABx} 2\left(2 \times \mathrm{d}, \mathrm{J}_{\mathrm{a}, \mathrm{b}}=11.5\right.$ $\mathrm{Hz}, 2 \mathrm{H}, \mathrm{CH}_{2}$ ). ${ }^{13} \mathrm{C}-\mathrm{NMR}\left(100 \mathrm{MHz}, \mathrm{CDCl}_{3}\right.$ ): $\delta 214.2$ (quat.), 136.5/129.0/128.6 (tert.), 127.2 (quat.), 
$56.7 / 52.8$ (tert.), 52.3 (quat.), 44.6/42.2/41.7 (tert.), 40.9 (sec.), 40.7/39.3 (tert.). IR $\left(\mathrm{CH}_{2} \mathrm{Cl}_{2}\right):$ v 3010-2820 (C-H, sat.), 1755 (C=O), 1580 (C=C, conj.) cm-1. EI/MS: m/e (\%) $302\left(3, \mathrm{M}^{+}\right), 274\left(25, \mathrm{M}^{+}-\mathrm{CO}\right), 236(14$, $\left.\mathrm{M}^{+}-\mathrm{C}_{5} \mathrm{H}_{6}\right), 145\left(38, \mathrm{M}^{+}{ }^{80} \mathrm{SePh}\right), 117\left(100, \mathrm{M}^{+}-\mathrm{SePh}-\mathrm{CO}\right), 66\left(3, \mathrm{C}_{5} \mathrm{H}_{6}{ }^{+}\right)$. El/HRMS m/e: 302.0209 [calc.for $\mathrm{C}_{16} \mathrm{H}_{14} \mathrm{O}^{80} \mathrm{Se}\left(\mathrm{M}^{+}\right):$302.0210].

\section{6-Methoxy-endo-tricyclo/5.2.1.0 ${ }^{2,6}$ Ideca-4,8-dien-3-one 19}

Crystalline bromide $\underline{\mathbf{7 d}}(100 \mathrm{mg}, 0.44 \mathrm{mmol})$ was added to a solution of potasium hydroxide $(20 \%, 10 \mathrm{ml})$ in methanol with stirring while cooling (ice-water). Stirring was continued until crystalline $\underline{\mathbf{7 d}}$ had complete disappeared. The mixture was neutralized and concentrated. Water $(10 \mathrm{ml})$ was added followed by extraction with ether $(3 \mathrm{x})$, several washing with brine and water, drying $\left(\mathrm{Na}_{2} \mathrm{SO}_{4}\right)$ and concentration in vacuo to give 19 as a viscous oil ( $80 \mathrm{mg}$, yield is $84 \%$ by GC). Pure $\underline{19}$ can be obtained by flash chromatography ( $\mathrm{n}$-hexane/EtOAc $=5 / 1$ ) as a colorless oil.

19: ${ }^{\mathrm{I}} \mathrm{H}-\mathrm{NMR}\left(400 \mathrm{MHz}, \mathrm{CDCl}_{3}\right): \delta 7.29\left(\mathrm{~d}, \mathrm{~J}_{4.5}=5.8 \mathrm{~Hz}, 1 \mathrm{H}, \mathrm{H}_{5}\right), 6.06\left(\mathrm{~d}, \mathrm{~J}_{4,5}=5.8 \mathrm{~Hz}, 1 \mathrm{H}, \mathrm{H}_{4}\right), 6.00 \mathrm{~A}$ of $\mathrm{AB}\left(\mathrm{dd}, \mathrm{J}_{8,9}=5.6 \mathrm{~Hz}, \mathrm{~J}_{1,9}\right.$ resp. $\mathrm{J}_{7,8}=2.8 \mathrm{~Hz}, 1 \mathrm{H}, \mathrm{H}_{8}$ or $\mathrm{H}_{9}$ ), $5.96 \mathrm{~B}$ of $\mathrm{AB}\left(\mathrm{dd}, \mathrm{J}_{8,9}=5.6 \mathrm{~Hz}, \mathrm{~J}_{1,9}\right.$ resp. $\mathrm{J}_{7,8}=3.1$ $\mathrm{Hz}, 1 \mathrm{H}, \mathrm{H}_{8}$ or $\mathrm{H}_{9}$ ), $3.31\left(\mathrm{~s}, 3 \mathrm{H}, \mathrm{OCH}_{3}\right), 3.22$ and $2.86\left(2 \mathrm{x}\right.$ brs, $2 \mathrm{H}, \mathrm{H}_{1}$ and $\left.\mathrm{H}_{7}\right), 2.77\left(\mathrm{~d}, \mathrm{~J}_{1,2}=4.7 \mathrm{~Hz}, 1 \mathrm{H}\right.$, $\left.\mathrm{H}_{2}\right), 2.20 \mathrm{~A}$ of $\mathrm{AB}\left(\mathrm{d}, \mathrm{J}_{10 \mathrm{a}, 10 \mathrm{~s}}=8.5 \mathrm{~Hz}, 1 \mathrm{H}, \mathrm{H}_{10 \mathrm{~s}}\right), 1.88 \mathrm{~B}$ of $\mathrm{AB}\left(\mathrm{dt}, \mathrm{J}_{10 \mathrm{a}, 10 \mathrm{~s}}=8.5 \mathrm{~Hz}, \mathrm{~J}_{10 \mathrm{a}, 1}=\mathrm{J}_{10 \mathrm{a}, 7}=1.6 \mathrm{~Hz}\right.$, $\left.1 \mathrm{H}, \mathrm{H}_{10 \mathrm{a}}\right)$. IR $\left(\mathrm{CH}_{2} \mathrm{Cl}_{2}\right):$ v 3100-3020 (C-H, unsat.), 3010-2820 (C-H, sat.), $1700(\mathrm{C}=\mathrm{O}), 1580(\mathrm{C}=\mathrm{C}$, conj.) $\mathrm{cm}^{-1}$. EI/MS: m/e (\%) $176\left(14, \mathrm{M}^{+}\right), 148\left(44, \mathrm{M}^{+}-\mathrm{CO}\right), 111\left(100, \mathrm{M}^{+}+1-\mathrm{C}_{5} \mathrm{H}_{6}\right), 81$ (74, $\left.\mathrm{M}^{+}-\mathrm{C}_{5} \mathrm{H}_{6}-\mathrm{OCH}_{3}\right), 66\left(93, \mathrm{C}_{5} \mathrm{H}_{6}{ }^{+}\right)$. EL/HRMS m/e: 176.0837 [calc.for $\mathrm{C}_{11} \mathrm{H}_{12} \mathrm{O}_{2}\left(\mathrm{M}^{+}\right)$: 176.0837].

\section{8-Methoxy-pentacyclo $\left[5 \cdot 3 \cdot 0 \cdot 0^{2,5} \cdot 0^{3,9} \cdot 0^{4,8}\right]$ deca-6-one 20}

A solution of $19(25 \mathrm{mg})$ in toluene $(2.5 \mathrm{ml})$ was irradiated for 4 hrs using a high-pressure mercury arc and a Pyrex filter. Concentration in vacuo gave $\underline{\mathbf{2 0}}(25 \mathrm{mg}, 100 \%)$ as a pure white solid.

20: ${ }^{1} \mathrm{H}-\mathrm{NMR}\left(400 \mathrm{MHz}, \mathrm{CDCl}_{3}\right): \delta 3.20\left(\mathrm{~s}, 3 \mathrm{H}, \mathrm{OCH}_{3}\right), 3.15-2.80\left(\mathrm{~m}, 5 \mathrm{H}, \mathrm{H}_{4,6-9}\right), 2.58\left(\mathrm{~m}, 1 \mathrm{H}, \mathrm{H}_{2}\right), 2.35$ $\left(\mathrm{m}, \mathrm{lH}, \mathrm{H}_{5}\right), 1.99$ and $1.59 \mathrm{AB}\left(2 \mathrm{xd}, \mathrm{J}_{10 \mathrm{a}, 10 \mathrm{~s}}=11.6 \mathrm{~Hz}, 1 \mathrm{H}, \mathrm{H}_{10}\right)$. IR $\left(\mathrm{CH}_{2} \mathrm{Cl}_{2}\right)$ : v 3020-2820 (C-H, sat.), $1755(\mathrm{C}=\mathrm{O}) \mathrm{cm}^{-1}$. EI/MS: m/e (\%) $176\left(3, \mathrm{M}^{+}\right), 148\left(53, \mathrm{M}^{+}-\mathrm{CO}\right), 66\left(67, \mathrm{C}_{5} \mathrm{H}_{6}{ }^{+}\right)$. EI/HRMS m/e: 176.0835 [calc.for $\mathrm{C}_{11} \mathrm{H}_{12} \mathrm{O}_{2}\left(\mathrm{M}^{+}\right)$: 176.0837 ].

Heptacyclo $996 \cdot 1 \cdot 1^{5,8} \cdot 1^{12,15} \cdot 0^{2,10} \cdot 0^{4,9} \cdot 0^{11,16}$ eicosa-4(9),6,13,16,-tetr aene-3,18-dione 21

A solution of $\underline{7 \mathbf{d}}\left(115 \mathrm{mg}, 0.5 \mathrm{mmol},[\alpha]_{\mathrm{D}}{ }^{25}=-222^{\circ}, \mathrm{c}=0.69, \mathrm{CH}_{3} \mathrm{OH}\right)$ in $\mathrm{CH}_{3} \mathrm{OH}(12 \mathrm{ml})$ and $\mathrm{Et}_{3} \mathrm{~N}(3 \mathrm{ml})$ was refluxed for $24 \mathrm{~h}$. Concentration in vacuo and subsequent flash chromatography (n-hexane/EtOAc $=$ $3 / 1)$ gave 21 (70 $\mathrm{mg},>95 \%$ ) as a white solid.

21: m.p.: $179^{\circ} \mathrm{C}$, decomposition (ethyl acetate), $[\alpha]_{D}{ }^{25}=-90.6^{\circ}, \mathrm{c}=1.14, \mathrm{CHCl}_{3}$ ). ${ }^{1} \mathrm{H}-\mathrm{NMR}(400 \mathrm{MHz}$, $\mathrm{CDCl}_{3}$ ): $\delta 6.91 \mathrm{~A}$ of $\mathrm{AB}\left(\mathrm{dd}, \mathrm{J}_{6,7}=5.1 \mathrm{~Hz}, \mathrm{~J}_{5,6}\right.$ resp. $\mathrm{J}_{7,8}=3.1 \mathrm{~Hz}, 1 \mathrm{H}, \mathrm{H}_{6}$ or $\left.\mathrm{H}_{7}\right), 6.82$ B of $\mathrm{AB}\left(\mathrm{dd}, \mathrm{J}_{6,7}=5.1\right.$ $\mathrm{Hz}, \mathrm{J}_{5,6}$ resp. $\mathrm{J}_{7,8}=3.2 \mathrm{~Hz}, 1 \mathrm{H}, \mathrm{H}_{6}$ or $\left.\mathrm{H}_{7}\right), 6.61 \mathrm{~A}$ of $\mathrm{AB}\left(\mathrm{dd}, \mathrm{J}_{13,14}=5.4 \mathrm{~Hz}, \mathrm{~J}_{12,13}\right.$ resp. $\mathrm{J}_{14,15}=3.0 \mathrm{~Hz}, 1 \mathrm{H}$, $\mathrm{H}_{13}$ or $\mathrm{H}_{14}$ ), $5.94 \mathrm{~B}$ of $\mathrm{AB}$ (dd, $\mathrm{J}_{13,14}=5.4 \mathrm{~Hz}, \mathrm{~J}_{12,13}$ resp. $\mathrm{J}_{14,15}=3.2 \mathrm{~Hz}, 1 \mathrm{H}, \mathrm{H}_{13}$ or $\left.\mathrm{H}_{14}\right), 5.64\left(\mathrm{dd}, \mathrm{J}_{1,17}=3.5\right.$ $\left.\mathrm{Hz}, 1 \mathrm{H}, \mathrm{H}_{17}\right), 3.78$ and $3.61\left(2 \mathrm{x}\right.$ brs, $2 \mathrm{H}, \mathrm{H}_{5}$ and $\left.\mathrm{H}_{8}\right), 3.42-3.36(\mathrm{~m}, 3 \mathrm{H}), 3.14\left(\mathrm{~d}, \mathrm{~J}_{2,10}=5.7 \mathrm{~Hz}, 1 \mathrm{H}\right), 3.07$ (brs, $1 \mathrm{H}$ ), $2.49 \mathrm{~A}$ of $\mathrm{AB}\left(\mathrm{dt}, \mathrm{J}_{20 \mathrm{a}, 20 \mathrm{~s}}=6.8 \mathrm{~Hz}, \mathrm{~J}=1.5 \mathrm{~Hz}, 1 \mathrm{H}\right.$, one of $\left.\mathrm{H}_{20}\right), 2.30 \mathrm{~B}$ of $\mathrm{AB}\left(\mathrm{d}, \mathrm{J}_{20 \mathrm{a}, 20 \mathrm{~s}}=6.8 \mathrm{~Hz}\right.$, $1 \mathrm{H}$, one of $\left.\mathrm{H}_{20}\right), 2.01 \mathrm{~A}$ of $\mathrm{AB}\left(\mathrm{d}, \mathrm{J}_{19 \mathrm{a}, 19 \mathrm{~s}}=8.8 \mathrm{~Hz}, 1 \mathrm{H}\right.$, one of $\left.\mathrm{H}_{19}\right), 1.98 \mathrm{~B}$ of $\mathrm{AB}\left(\mathrm{dt}, \mathrm{J}_{19 \mathrm{a}, 19 \mathrm{~s}}=8.8 \mathrm{~Hz}, \mathrm{~J}=1.6\right.$ $\mathrm{Hz}, 1 \mathrm{H}$, One of $\left.\mathrm{H}_{29}\right) .{ }^{13} \mathrm{C}-\mathrm{NMR}\left(100 \mathrm{MHz}, \mathrm{H}\right.$-dec., $\mathrm{CDCl}_{3}$ ): $\delta$ 199.2/196.3/195.2/167.5/150.2 (quat.), 145.0/142.2/135.5/133.9/113.7 (tert.), 74.0 (sec.), 68.3 (quat.), 55.7/53.8 (tert.), 53.1 (sec.), 
52.3/45.0/44.2/42.0/40.2 (tert.). IR $\left(\mathrm{CH}_{2} \mathrm{Cl}_{2}\right): v$ 3120-3030 (C-H, unsat.), 3020-2820 (C-H, sat.), 1770 $(\mathrm{C}=\mathrm{O}), 1680\left(\mathrm{C}=\mathrm{O}\right.$, unsat.), 1590 ( $\mathrm{C}=\mathrm{C}$, conj. $\mathrm{cm}^{-1}$. Cl/MS: $\mathrm{m} / \mathrm{e}(\%) 289\left(3, \mathrm{M}^{+}+1\right), 261\left(12, \mathrm{M}^{+}+1-\mathrm{CO}\right)$, $194\left(100, \mathrm{M}^{+}-\mathrm{CO}-\mathrm{C}_{5} \mathrm{H}_{6}\right), 66\left(6, \mathrm{C}_{5} \mathrm{H}_{6}{ }^{+}\right)$. EI/HRMS m/e: 289.1233 [calc.for $\mathrm{C}_{20} \mathrm{H}_{17} \mathrm{O}_{2}\left(\mathrm{M}^{+}+1\right): 289.1229$ ].

cis-endo-Pentacyclo $19 \cdot 2 \cdot 1 \cdot 1^{5,8} \cdot 0^{2,10} \cdot 0^{4,9}$ pentadeca-2(10),6,12-trien-3-o ne 22 and anti-endo- pentacyclo$\left[9.2 .1 .1^{5,8} \cdot 0^{2,10} \cdot 0^{4,9}\right]$ pentadeca-2(10),6,12-trien-3-one 23

A mixture of $\underline{7 \mathrm{~d}}(115 \mathrm{mg}, 0.5 \mathrm{mmol})$ and cyclopentadiene $(0.5 \mathrm{ml})$ in methanol $(12 \mathrm{ml})$ and $\mathrm{Et}_{3} \mathrm{~N}(3 \mathrm{ml})$ was refluxed for $24 \mathrm{hrs}$. Concentration in vacuo and subsequent flash chromatography (n-hexane/EtOAc = 3/1) gave a mixture ( $85 \mathrm{mg}, 81 \%)$ of $\underline{\mathbf{2 2}}$ and $\underline{\mathbf{2 3}}$ as a white solid in $1: 2$ ratio.

22: ${ }^{1} \mathrm{H}-\mathrm{NMR}\left(400 \mathrm{MHz}, \mathrm{CDCl}_{3}\right): \delta 6.73 \mathrm{~A}$ of $\mathrm{AB}(\mathrm{dd}, \mathrm{J}=5.0 \mathrm{~Hz}, \mathrm{~J}=3.1 \mathrm{~Hz}, 1 \mathrm{H}), 6.67 \mathrm{~B}$ of $\mathrm{AB}(\mathrm{dd}, \mathrm{J}=5.0$ $\mathrm{Hz}, \mathrm{J}=3.2 \mathrm{~Hz}, 1 \mathrm{H}), 5.74 \mathrm{~A}$ of $\mathrm{AB}(\mathrm{dd}, \mathrm{J}=5.6 \mathrm{~Hz}, \mathrm{~J}=2.9 \mathrm{~Hz}, 1 \mathrm{H}), 5.37 \mathrm{~B}$ of $\mathrm{AB}(\mathrm{dd}, \mathrm{J}=5.6 \mathrm{~Hz}, \mathrm{~J}=2.9 \mathrm{~Hz}$, $1 \mathrm{H}), 3.61$ and $3.48(2 \times$ brs, $2 \mathrm{H}), 3.46$ and $3.19 \mathrm{AB}(2 \times \mathrm{t}, \mathrm{J}=4.6 \mathrm{~Hz}, 2 \mathrm{H}), 3.09$ and $2.95(2 \mathrm{x}$ brs, $2 \mathrm{H}), 2.37$ and $2.31 \mathrm{AB}(2 \times \mathrm{d}, \mathrm{J}=6.6 \mathrm{~Hz}, 2 \mathrm{H}), 1.72 \mathrm{~A}$ of $\mathrm{AB}(\mathrm{dt}, \mathrm{J}=8.4 \mathrm{~Hz}, \mathrm{~J}=1.8 \mathrm{~Hz}, 1 \mathrm{H}), 1.59 \mathrm{~B}$ of $\mathrm{AB}(\mathrm{d}, \mathrm{J}=8.4 \mathrm{~Hz}$, 1H). CI/MS: m/e (\%) $211\left(100, \mathrm{M}^{+}+1\right), 182\left(76, \mathrm{M}^{+}-\mathrm{CO}\right), 145\left(39, \mathrm{M}^{+}+1-\mathrm{C}_{5} \mathrm{H}_{6}\right), 116\left(98, \mathrm{M}^{+}-\mathrm{C}_{5} \mathrm{H}_{6}-\mathrm{CO}\right)$, $66\left(9, \mathrm{C}_{5} \mathrm{H}_{6}^{+}\right)$.

23: $\left.{ }^{1} \mathrm{H}-\mathrm{NMR}(400 \mathrm{MHz}, \mathrm{CDCl})_{3}\right): \delta 6.86 \mathrm{~A}$ of $\mathrm{AB}(\mathrm{dd}, \mathrm{J}=5.1 \mathrm{~Hz}, \mathrm{~J}=3.1 \mathrm{~Hz}, 1 \mathrm{H}), 6.75 \mathrm{~B}$ of $\mathrm{AB}(\mathrm{dd}, \mathrm{J}=5.1$ $\mathrm{Hz}, \mathrm{J}=3.2 \mathrm{~Hz}, 1 \mathrm{H}), 5.99 \mathrm{~A}$ of $\mathrm{AB}(\mathrm{dd}, \mathrm{J}=5.6 \mathrm{~Hz}, \mathrm{~J}=2.9 \mathrm{~Hz}, 1 \mathrm{H}), 5.81 \mathrm{~B}$ of $\mathrm{AB}$ (dd, J=5.6 Hz, J=2.9 Hz, $1 \mathrm{H}), 3.61$ and $3.49(2 \mathrm{xbs}, 2 \mathrm{H}), 3.22$ and $3.14 \mathrm{AB}(2 \times \mathrm{t}, \mathrm{J}=4.6 \mathrm{~Hz}, 2 \mathrm{H}), 3.18$ and $3.01(2 \mathrm{x} \mathrm{bs}, 2 \mathrm{H}), 2.38 \mathrm{~A}$ of $\mathrm{AB}\left(\mathrm{dt}, \mathrm{J}=6.6 \mathrm{~Hz}, \mathrm{~J}=1.5 \mathrm{~Hz}, 1 \mathrm{H}, \mathrm{H}_{10 \mathrm{~s}}\right), 2.22 \mathrm{~B}$ of $\mathrm{AB}(\mathrm{d}, \mathrm{J}=6.6 \mathrm{~Hz}, 1 \mathrm{H}), 1.82 \mathrm{~A}$ of $\mathrm{AB}(\mathrm{dt}, \mathrm{J}=8.4 \mathrm{~Hz}$, $\mathrm{J}=1.5 \mathrm{~Hz}, 1 \mathrm{H}), 1.61 \mathrm{~B}$ of $\mathrm{AB}(\mathrm{d}, \mathrm{J}=8.4 \mathrm{~Hz}, 1 \mathrm{H}) . \mathrm{CI} / \mathrm{MS}: \mathrm{m} / \mathrm{e}(\%) 211\left(65, \mathrm{M}^{+}+1\right), 182\left(71, \mathrm{M}^{+} \mathrm{CO}\right), 145$ $\left(31, \mathrm{M}^{+}+1-\mathrm{C}_{5} \mathrm{H}_{6}\right), 116\left(100, \mathrm{M}^{+}-\mathrm{C}_{5} \mathrm{H}_{6}-\mathrm{CO}\right), 66\left(12, \mathrm{C}_{5} \mathrm{H}_{6}{ }^{+}\right)$. IR of mixture $\left(\mathrm{CH}_{2} \mathrm{Cl}_{2}\right)$ : v 3120-3030 $(\mathrm{C}-\mathrm{H}$, unsat.), 3020-2820 (C-H, sat.), 1670 ( $\mathrm{C}=\mathrm{O}$, unsat.), $1590(\mathrm{C}=\mathrm{C}$, conj. $) \mathrm{cm}^{-1}$.

endo-cis-endo-Pentacyclo $\left[9.2 .1 .1^{5,8} \cdot 0^{2,10} \cdot 0^{4,9}\right]$ pentadeca-6,12-dien-3-one 24 and endo-anti-endo- pentacyclo/9.2.1.1 $1^{5,8} \cdot 0^{2,10} \cdot 0^{4,9}$ Ipentadeca-6,12-dien-3-one 25

A mixture of $\underline{22}$ and $\underline{23}(210 \mathrm{mg}, 1 \mathrm{mmol})$ in dry THF $(5 \mathrm{ml})$ was added to a deep blue solution of lithium in ammonia [made from lithium metal $(50 \mathrm{mg})$ and liquid ammonia $(10 \mathrm{ml})$ ] at $-78^{\circ} \mathrm{C}$ with stirring]. The reaction was continued for $10 \mathrm{~min}$. and stopped by adding solid $\mathrm{NH}_{4} \mathrm{Cl}$ until the blue colour disappeared. After evaporation of the ammonia, water $(5 \mathrm{ml})$ was added and the mixture was extracted with ether $(3 \mathrm{x})$, washed with brine and water, dried (over $\mathrm{Na}_{2} \mathrm{SO}_{4}$ ) and concentrated to give an oil (205mg).

This oil was redissolved in dichloromethane $(10 \mathrm{ml})$ and treated with pyridinium chlorochromate $(320 \mathrm{mg}$, $1.5 \mathrm{mmol}$ ) for $2 \mathrm{hrs}$ at room temp. Ether $\left(30 \mathrm{ml}\right.$ ) was added, the mixture filtered and dried (over $\mathrm{MgSO}_{4}$ ) and concentrated in vacuo. Subsequent flash chromatography (n-hexane/EtOAc $=10 / 1)$ gave 24 (60 mg, $29 \%$ ) and 25 (105 $\mathrm{mg}, 50 \%)$.

24: ${ }^{1} \mathrm{H}-\mathrm{NMR}\left(400 \mathrm{MHz}, \mathrm{CDCl}_{3}\right.$ ): $\delta 5.97 \mathrm{~A}$ of $\mathrm{AB}\left(\mathrm{dd}, \mathrm{J}_{\mathrm{a}, \mathrm{b}}=5.7 \mathrm{~Hz}, \mathrm{~J}=3.1 \mathrm{~Hz}, 2 \mathrm{H}\right), 5.90 \mathrm{~B}$ of $\mathrm{AB}(\mathrm{dd}$, $\left.\mathrm{J}_{\mathrm{a}, \mathrm{b}}=5.7 \mathrm{~Hz}, \mathrm{~J}=3.0 \mathrm{~Hz}, 2 \mathrm{H}\right), 3.28-3.17(\mathrm{~m}, 4 \mathrm{H}), 2.97$ and $2.88(2 \mathrm{x}$ bs, $4 \mathrm{H}), 1.52$ and $1.38 \mathrm{AB}(2 \mathrm{x} \mathrm{d}, \mathrm{J}=7.9$ $\mathrm{Hz}, 4 \mathrm{H})$. IR $\left(\mathrm{CH}_{2} \mathrm{Cl}_{2}\right):$ v 3100-3020 (C-H, unsat.), 3010-2820 (C-H, sat.), $1720(\mathrm{C}=\mathrm{O}) \mathrm{cm}^{-1}$. CI/MS: m/e (\%) $212\left(6, \mathrm{M}^{+}\right), 184\left(12, \mathrm{M}^{+}-\mathrm{CO}\right), 147\left(23, \mathrm{M}^{+}+1-\mathrm{C}_{5} \mathrm{H}_{6}\right), 66\left(100, \mathrm{C}_{5} \mathrm{H}_{6}{ }^{+}\right)$. EI/HRMS m/e: 212.1199 [calc.for $\left.\mathrm{C}_{15} \mathrm{H}_{16} \mathrm{O}\left(\mathrm{M}^{+}\right): 212.1201\right]$.

25: ${ }^{1} \mathrm{H}-\mathrm{NMR}\left(400 \mathrm{MHz}, \mathrm{CDCl}_{3}\right.$ ): $\delta 6.20 \mathrm{~A}$ of $\mathrm{AB}$ (dd, J=5.7 Hz, J=3.1 Hz, 2H), 6.07 B of $\mathrm{AB}(\mathrm{dd}, \mathrm{J}=5.7$ $\mathrm{Hz}, \mathrm{J}=3.1 \mathrm{~Hz}, 2 \mathrm{H}), 3.07(2 \mathrm{x}$ brs, $4 \mathrm{H}), 2.60 \mathrm{~A}$ of $\mathrm{AB}(\mathrm{dd}, \mathrm{J}=8.5 \mathrm{~Hz}, \mathrm{~J}=4.8 \mathrm{~Hz}, 2 \mathrm{H}), 2.42 \mathrm{~B}$ of $\mathrm{AB}(\mathrm{dd}, \mathrm{J}=8.5$ 
$\mathrm{Hz}, \mathrm{J}=3.6 \mathrm{~Hz}, 2 \mathrm{H}), 1.45 \mathrm{~A}$ of $\mathrm{AB}(\mathrm{dt}, \mathrm{J}=8.2 \mathrm{~Hz}, \mathrm{~J}=1.6 \mathrm{~Hz}, 2 \mathrm{H}), 1.27 \mathrm{~B}$ of $\mathrm{AB}(\mathrm{d}, \mathrm{J}=8.2 \mathrm{~Hz}, 2 \mathrm{H})$. IR $\left(\mathrm{CH}_{2} \mathrm{Cl}_{2}\right.$ ): v 3100-3020 (C-H, unsat.), 3010-2820 (C-H, sat.), $1720(\mathrm{C}=\mathrm{O}) \mathrm{cm}^{-1}$. Cl/MS: m/e (\%) $212(0.7$, $\left.\mathrm{M}^{+}\right), 147\left(100, \mathrm{M}^{+}+1-\mathrm{C}_{5} \mathrm{H}_{6}\right), 66\left(88, \mathrm{C}_{5} \mathrm{H}_{6}^{+}\right)$. EI/HRMS m/e: 212.1199 [calc.for $\mathrm{C}_{15} \mathrm{H}_{16} \mathrm{O}\left(\mathrm{M}^{+}\right): 212.1201$ ]

endo-anti-exo-Pentacyclo $19.2 .1 .1^{5,8} \cdot 0^{2,10} \cdot 0^{4,9}$ Ipentadeca-6,12-dien-3-one $\underline{27}$ and exo-anti-exo-pentacyclo$\left[9.2 .1 .1^{5,8} \cdot 0^{2,10} \cdot 0^{4,9}\right]$ pentadeca-6,12-dien-3-one 28

A mixture of exo-tricyclodecadienone $\underline{\mathbf{2}} 6\left(440 \mathrm{mg}, 3 \mathrm{mmol}\right.$ ), cyclopentadiene (400 mg, $6 \mathrm{mmol}$ ) and $\mathrm{AlCl}_{3}$ $(80 \mathrm{mg}, 0.6 \mathrm{mmol})$ in dried benzene $(15 \mathrm{ml})$ was stirred for $4 \mathrm{~h}$ at room temp. Concentration in vacuo and subsequent flash chromatography (n-hexane/EtOAc $=19 / 1)$ gave $\underline{27}(185 \mathrm{mg}, 29 \%)$ and $\underline{28}(365 \mathrm{mg}$, $57 \%$ ).

27: ${ }^{1} \mathrm{H}-\mathrm{NMR}\left(400 \mathrm{MHz}, \mathrm{CDCl}_{3}\right.$ ): $\delta 6.17 \mathrm{~A}$ of $\mathrm{AB}$ (dd, J=5.7 Hz and $\left.3.1 \mathrm{~Hz}, 1 \mathrm{H}\right), 6.14 \mathrm{~A}$ of $\mathrm{AB}$ (dd, J=5.7 $\mathrm{Hz}$ and $3.1 \mathrm{~Hz}, 1 \mathrm{H}), 6.09-6.05 \mathrm{~B}$ of $\mathrm{AB}(\mathrm{m}, 2 \mathrm{H}), 3.22-3.20(\mathrm{~m}, 1 \mathrm{H}), 3.11-3.07(\mathrm{~m}, 2 \mathrm{H}), 2.97$ and $2.83(2 \mathrm{x}$ bs, $2 \mathrm{H}), 2.51$ (ddd, $\mathrm{J}=2.1,4.1$ and $8.6 \mathrm{~Hz}, 1 \mathrm{H}), 1.94 \mathrm{~A}$ of $\mathrm{AB}(\mathrm{d}, \mathrm{J}=7.7 \mathrm{~Hz}, 1 \mathrm{H}), 1.78 \mathrm{~B}$ of $\mathrm{AB}(\mathrm{d}, \mathrm{J}=7.7 \mathrm{~Hz}$, $1 \mathrm{H}), 1.51 \mathrm{~A}$ of $\mathrm{AB}(\mathrm{d}, \mathrm{J}=8.4 \mathrm{~Hz}, 1 \mathrm{H}), 1.37-1.33(\mathrm{~m}, 2 \mathrm{H}), 1.27 \mathrm{~B}$ of $\mathrm{AB}(\mathrm{d}, \mathrm{J}=8.4 \mathrm{~Hz}, 1 \mathrm{H})$.

28: ${ }^{1} \mathrm{H}-\mathrm{NMR}\left(400 \mathrm{MHz}, \mathrm{CDCl}_{3}\right): \delta 6.19 \mathrm{~A}$ of $\mathrm{AB}(\mathrm{dd}, \mathrm{J}=5.6 \mathrm{~Hz}, \mathrm{~J}=3.0 \mathrm{~Hz}, 2 \mathrm{H}), 6.14 \mathrm{~B}$ of $\mathrm{AB}(\mathrm{dd}, \mathrm{J}=5.6$ $\mathrm{Hz}, \mathrm{J}=2.9 \mathrm{~Hz}, 2 \mathrm{H}), 3.07$ and $2.86(2 \mathrm{x}$ brs, $2 \times 2 \mathrm{H}), 2.43$ and $1.90 \mathrm{AB}\left(\mathrm{dd}, \mathrm{J}_{1}=\mathrm{J}_{2}=8.5 \mathrm{~Hz}, 2 \times 2 \mathrm{H}\right), 1.39$ and $1.30 \mathrm{AB}(\mathrm{d}, \mathrm{J}=9.0 \mathrm{~Hz}, 2 \times 2 \mathrm{H})$. IR $\left(\mathrm{CH}_{2} \mathrm{Cl}_{2}\right): v$ 3100-3020 (C-H, unsat.), 3010-2820 (C-H, sat.), 1710 $(\mathrm{C}=\mathrm{O}) \mathrm{cm}^{-1}$. CI/MS: $\mathrm{m} / \mathrm{e}(\%) 212\left(2, \mathrm{M}^{+}\right), 147\left(79, \mathrm{M}^{+}+1-\mathrm{C}_{5} \mathrm{H}_{6}\right), 66\left(100, \mathrm{C}_{5} \mathrm{H}_{6}{ }^{+}\right) . \quad$ EI/HRMS m/e: 212.1202 [calc.for $\mathrm{C}_{15} \mathrm{H}_{16} \mathrm{O}\left(\mathrm{M}^{+}\right): 212.1201$ ].

Heptacyclol7.5.1. $0^{2,8} \cdot 0^{3,7} \cdot 0^{4,13} \cdot 0^{6,12} \cdot 0^{10,14}$ lpentadeca-11-one 30

A solution of $\underline{\mathbf{2 4}}(45 \mathrm{mg}, 0.22 \mathrm{mmol})$ in a mixture of $10 \%$ acetone in benzene $(10 \mathrm{ml})$ was irradiated overnight using a high-pressure mercury arc and a Pyrex filter. Concentration in vacuo and subsequent chromatography (n-hexane/EtOAc $=20 / 1)$ gave $\underline{30}(27 \mathrm{mg}, 60 \%)$ as a pure white solid.

30: m.p.: $137-139^{\circ} \mathrm{C}$ (EtOAc in n-hexane)[Lit ${ }^{19}$ m.p.: $123-125^{\circ} \mathrm{C}$ ]. ${ }^{1} \mathrm{H}-\mathrm{NMR}\left(400 \mathrm{MHz}, \mathrm{CDCl}_{3}\right): \delta 2.76$ $(\mathrm{m}, 6 \mathrm{H}), 2.43(\mathrm{~d}, \mathrm{~J}=7.1 \mathrm{~Hz}, 2 \mathrm{H}), 2.37,2.27$ and $1.60(3 \mathrm{x}$ bs, $3 \times 2 \mathrm{H}), 1.61 \mathrm{~A}$ of $\mathrm{AB}(\mathrm{dd}, \mathrm{J}=9.3 \mathrm{~Hz}, \mathrm{~J}=1.4$ $\mathrm{Hz}, 2 \mathrm{H}$ ), $1.41 \mathrm{~B}$ of $\mathrm{AB}\left(\mathrm{dd}, \mathrm{J}=9.2 \mathrm{~Hz}, \mathrm{~J}=1.3 \mathrm{~Hz}, 2 \mathrm{H}\right.$ ). ${ }^{13} \mathrm{C}-\mathrm{NMR}\left(100 \mathrm{MHz}, \mathrm{CDCl}_{3}\right): \delta 219.7$ (quat.), 62.0 (tert.), 45.6 (sec.), 43.4/38.8/38.0/35.1/34.4 (tert.). IR $\left(\mathrm{CH}_{2} \mathrm{Cl}_{2}\right):$ v 3010-2820 (C-H, sat.), 1715 (C=O) $\mathrm{cm}^{-1}$. CI/MS: $\mathrm{m} / \mathrm{e}(\%) 212\left(61, \mathrm{M}^{+}\right), 184\left(55, \mathrm{M}^{+}-\mathrm{CO}\right), 66\left(23, \mathrm{C}_{5} \mathrm{H}_{6}{ }^{+}\right)$. EI/HRMS m/e: 212.1202 [calc.for $\left.\mathrm{C}_{15} \mathrm{H}_{16} \mathrm{O}\left(\mathrm{M}^{+}\right): 212.1201\right]$.

\section{References and Notes}

1. For some recent representative examples, see: (a) Klunder, A.J.H.; Huizinga, W.B.; Sessink, P.J.M.; Zwanenburg, B., Tetrahedron Lett., 1987, 28, 357. (b) Klunder, A.J.H.; Houwen-Claassen, A.A.M; Kooy, M.G.; Zwanenburg, B., ibid., 1987, 28, 1329. (c) Lange, A.A.M.; Klunder, A.J.H.; Zwanenburg, B., ibid., 1989, 30, 127. (d) Houwen-Claassen, A.A.M.; Klunder, A.J.H.; Zwanenburg, B., Tetrahedron, 1989, 45, 7134. (e) Grieco, P.A.; Abood, N., J. Org. Chem., 1989, 54, 6008. (f) Grieco, P.A.; Abood, N., J. Chem. Soc. Chem. Commun., 1990, 410. (g) Garland, R.B.; Miyano, M.; Pireh, D.; Clare, M.; Finnegan, P.M.; Swenton, L., J. Org. Chem., 1990, 55, 5854. (h) Klunder, A.J.H.; Zwanenburg, B.; Liu, Z.Y., Tetrahedron Lett., 1991, 32, 3131. (i) Lange, J.H.M.; Klunder, A.J.H.; Zwanenburg, B., Tetrahedron, 1991, 47, 1509. (j) Takano, S.; Moriya, M.; Ogasawara, K., Tetrahedron Lett., 1992, 33, 1909. (k) Liu, Z.Y.; He L.; Zheng, H., Synlett., 1993, 191. (1) Liu, Z.Y.; Chu, X.J., Tetrahedron Lett., 1993, 34, 3885. (m) Zhu, J.; Klunder A.J.H.; Zwanenburg, B., Tetrahedron, 1994, 50, 10597. (n) Ogasawara, K., Pure \& Appl. Chem., 1994, 66, 2119.

2. (a) Klunder, A.J.H.; Huizinga, W.B.; Hulshof, A.J.M.; Zwanenburg, B., Tetrahedron Lett., 1986, 27, 
2543. (b) Takano, S.; Inomata, K.; Takahashi, M.; Ogasawara, K., Synlett., 1991, 636. (c) Takano, S.; Inomata, K.; Ogasawara, K., J. Chem. Soc., Chem. Commun., 1989, 271. (d) Takano, S.; Inomata, K.; Ogasawara, K., Chem. Lett., 1989, 359. (e) Liu, Z.Y.; He, L.; Zheng, H., Tetrahedron Asymmetry, 1993, 4, 2277. (f) Sato, M.; Hattori, H.; Murakami, M.; Kaneko, C., Chem. Lett., 1993, 1919

3. (a) Dols, P.P.M.A.; Lacroix, L.; Klunder, A.J.H.; Zwanenburg, B., Tetrahedron Lett., 1991, 32 , 3739. (b) Childs, B.; Edwards, G.L., Tetrahedron Lett., 1993, 34, 5341. (c) Dols, P.P.M.A.; Klunder, A.J.H.; Zwanenburg, B., Tetrahedron, 1994, 50, 8515.

4. Zhu, J.; Yang, J-Y.; Klunder, A.J.H.; Liu, Z-Y.; Zwanenburg, B., Tetrahedron, submitted for publication.

5. Herz, W.; Iyer, V.S.; Nair, M.G., J. Org. Chem., 1975, 40, 3519. For a modified and improved procedure, see: Klunder, A.J.H.; de Valk, W.C.G.M.; Verlaak, J.M.J.; Schellekens, J.W.M.; Noordik, J.H.; Parthasarathi, V.; Zwanenburg, B., Tetrahedron, 1985, 41, 963.

6. (a) Iguchi, K.; Kaneta, S.; Mori, K.; Yamada, Y.; Honda, A.; Mori, Y., Tetrahedron Lett., 1985, 26 , 5787. (b) Nagaoka, H.; Iguchi, K.; Miyakoshi, T.; Yamada, N.; Yamada, Y., ibid., 1986, 27, 223. (c) Iguchi, K.; Kaneta, S.; Mori, K.; Yamada, Y.; Honda, A.; Mori, Y., J. Chem. Soc. Chem. Commun., 1986, 981 .

7. (a) Baker, B.J.; Okuda, R.K.; Yu, P.T.K.; Scheuer, P.J., J. Amer. Chem. Soc., 1985, 107, 2976. (b) Suzuki, M.; Morita, Y.; Yanagisawa, A.; Baker, B.J.; Scheuer, P.J.; Noyori, R., J. Org. Chem., 1988, 53, 286.

8. Zhu, J.; Klunder, A.J.H.; Zwanenburg, B. Tetrahedron Lett., 1993, 34, 3335.

9. For some representative publications, see: (a) Barton, D.H.R.; Crich, D.; Motherwell,W.B., J. Chem. Soc. Chem Commun., 1983, 939. (b) Barton, D.H.R.; Lacher, B.; Zard, S.Z., Tetrahedron Lett., 1987, 43, 4321. (c) Barton, D.H.R.; Crich, D.; Motherwell,W.B., Tetrahedron, 1985, 41, 3901.

10. Barton, D.H.R.; Ozbalik, N.; Schmitt, M., Tetrahedron Lett., 1989, 30, 3263. (c) Castagnino, E.; Corsano, S.; Barton, D.H.R., ibid., 1989, 30, 2983. (d) Tsanaktsidis, J.; Eaton, P.E., ibid., 1989, 30, 6967. (e) Hamdani, M.; Jeso, B.D.; Deleuze, H.; Maillard, B., Tetrahedron: Asymmetry, 1991, 2, 867. (f) Barton, D.H.R.; Dalko, P.; Gero, S.D., Tetrahedron Lett., 1991, 32, 2471. (g) Togo, H.; Fujii, M.; Ikuma, T.; Yokoyama, M., ibid., 1991, 32, 3377. (h) Scheumann, K.; Wahl, F.; Prinzbach, H., ibid., 1992, 33, 615. (i) Barton, D.H.R.; Gero, S.D.; Quiclet-Sire, B.; Samadi, M., Tetrahedron, $1992,48,1627$.

11. Sheldon, R.A; Kochi, J.K., Organic reactions, 1972, 19, 279.

12. Jasperse, C.P.; Curran, D.P.; Fevig, T.L., Chem. Reviews, 1991, 91, 1237.

13. Barton, D.H.R.; Bridon, D.; Zard, S.Z., Heterocycles, 1987, 25, 449.

14. (a) Nakayama, M.; Fukuoka, Y.; Nozaki, H.; Matsuo, A.; Hayashi, S., Chem. Lett., 1980, 1243. (b) Chen, B-C.; Weismiller, M.C.; Davis, F.A.; Boschelli, D.; Empfield, J.R.; Smith, III, A.B., Tetrahedron, 1991, 47, 173.

15. Barton, D.H.R.; Bridon, D.; Zard, S.Z., Tetrahedron, 1989, 45, 2615.

16. Smits, J.M.M.; Beurskens, P.T.H.; Zhu, J.; Klunder, A.J.H., to be published.

17. Ogliaruso, M.A.; Romanelli, M.G.; Becker, E.I., Chem. Reviews 1965, 65, 261.

18. Cookson, R.C.; Henstock, J.; Hudec, J., J. Amer. Chem. Soc., 1966, 88, 1059.

19. Mehta, G.; Padma, S., J. Amer. Chem. Soc., 1987, 109, 7230. 